\title{
Az emberi jogok területi tagoltsága és új, területi tipológiája
}

\section{ANDRÁSSY GYÖRGY ${ }^{1}$}

A tanulmány fó állitása az, hogy az Emberi Jogok Nemzetközi Törvényében (EJNT) elismert jogok terület szerint (is) tagolódnak, éspedig a) területhez nem kötött, b) területhez kötött és c) területileg vegyes jogokra. A területhez nem kötött jogok mindenkit megilletnek mindenhol, a területhez kötött jogok mindenkit megilletnek, de nem mindenhol, a területileg vegyes jogok pedig mindenkit megilletnek részint mindenhol, részint nem mindenhol. A területi tipológia ellentmondásban áll az EJNT-t alkotó fó okmányoknak azokkal a rendelkezéseivel, amelyek értelmében az okmányokban elismert valamennyi jog mindenkit megillet mindenhol, azaz területhez nem kötött jog. A tanulmány azonban feltárja az új tipológia logikai-matematikai alapját, és rávilágit, hogy ennek fényében az emlitett rendelkezések egy következtetés folyományai, a következtetés azonban logikailag hamis. Kimutatja továbbá, hogy az EJNT-ben elismert jogok mintegy 40\%-a részben vagy egészben területhez kötött jog, s ily módon az EJNT szóban forgó rendelkezései statisztikailag sem védhetők. A tanulmány foglalkozik az EJNT-nek az emberi jogok eredetére vonatkozó kitételeivel és a jogok háromszoros egyetemességének tézisével is, amellett érvelve, hogy nincs valós ellentmondás ezek és az új tipológia között. A tanulmány végül kitér a területi tipológia jelentőségére.

Kulcsszavak: emberi jogok, az EJNT-ben elismert emberi jogok terület szerinti tagoltsága és tipológiája, területhez nem kötött emberi jogok (mindenkit megilletnek mindenhol), területhez kötött emberi jogok (mindenkit megilletnek valahol), területileg vegyes emberi jogok (mindenkit megilletnek részben mindenhol, részben valahol)

\section{Territorial Division and a New Territorial Typology of Human Rights}

The main proposition of the study is that the rights recognised in the International Bill of Human Rights (IBHR) are (also) divided territorially, namely into a) non-territorial rights (which everyone has everywhere in the world), b) territorial rights (which everyone has somewhere in the world) and c) territorially mixed rights (which everyone has partly everywhere and partly somewhere in the world). This territorial division or typology is

1 Egyetemi tanár, Pécsi Tudományegyetem Állam- és Jogtudományi Kar, e-mail: andrassy. gyorgy@ajk.pte.hu 
in contradiction with those provisions of the main documents of the IBHR which imply that all human rights recognised in the said documents are non-territorial rights, that is, rights which everyone has everywhere in the world. However, the study explores the logical or mathematical basis of the new typology and highlights that in light of this basis, the provisions in question are results of a conclusion and as such are logically false. Further, the study shows that approximately 40 per cent of the rights recognised in the IBHR are either territorial or partly territorial rights and therefore, the said provisions of the IBHR are not even statistically defensible. Also, the study deals with those clauses of the IBHR which relate to the origin of human rights, as well as with the thesis of triple universality of human rights and argues that there is no real contradiction between these and the territorial typology. Finally, the study touches on the importance of the new typology.

Keywords: human rights, territorial division and typology of the rights recognised in the IBHR, non-territorial human rights, territorial human rights, territorially mixed human rights

\section{Bevezetés}

Az emberi jogokat általában nemzedékek szerint csoportosítják, ${ }^{2}$ de felosztják őket alapvető és nem alapvető jogokra, ${ }^{3}$ és különbséget tesznek e jogok nyugati és nem nyugati felfogásai között is. ${ }^{4}$ A jelen tanulmány az emberi jogoknak, illetve az emberi jogok nemzetközi jogában, s közelebbről az Emberi Jogok Nemzetközi Törvényében (EJNT) elismert jogoknak egy új tipológiáját vázolja fel és igazolja. Eszerint az EJNTben elismert jogok három csoportra tagolódnak: a) területhez nem kötött, b) területhez kötött és c) területileg vegyes jogokra. A területhez nem kötött jogok mindenkit megilletnek mindenhol, a területhez kötött jogok mindenkit megilletnek, de nem mindenhol, a területileg vegyes jogok mindenkit megilletnek részint mindenhol, részint nem mindenhol.

Csakhogy az uralkodó felfogás szerint az emberi jogok mindenkit megilletnek mindenhol, s így területhez kötött és területileg vegyes jogok nincsenek is. Emellett szól először is, hogy az EJNT-ben vannak olyan rendelkezések, amelyek úgyszólván ki is mondják, hogy az EJNT által elismert valamennyi jog mindenkit megillet minden országban, s erre utalnak (másodszor) az emberi jogok eredetére vonatkozó EJNT-

2 Karel Vašak: A 30-year Struggle. UNESCO Courier, 30. (1977), 11. 29.

3 Henry Shue: Basic Rights. Subsistence, Affluence, and U.S. Foreign Policy. Princeton, Princeton University Press, 1980.

4 Jack Donnelly: Universal Human Rights in Theory and Practice. Ithaca and London, Cornell University, 2003. 61-88 és 2013. 106-118. 
kitételek is. Végül pedig itt van az a természetjogi hagyományból megörökölt tétel, amely az emberi jogok tanában úgy szól, hogy az emberi jogok minden embert megilletnek mindenhol és minden időkben. A tanulmány szerint viszont mindezekben a területi tipológia ellen szóló rendelkezésekben, kitételekben, tételekben, illetve ezek uralkodó értelmezésében van valami hiba, az új tipológia pedig megalapozott.

De miért az EJNT-ben elismert jogokat osztályozza a tanulmány? Egyfelől azért, mert amióta kiépült az emberi jogok nemzetközi védelmének rendszere, az emberi jogok belső joga is nagyrészt az emberi jogok nemzetközi jogához igazodik, az emberi jogok nemzetközi jogának középpontjában pedig az Egyesült Nemzetek Szervezetének (ENSZ) égisze alatt elfogadott EJNT áll: mind a mai napig az EJNT képezi „az emberi jogok védelmének magvát a világközösségben".5 A másik ok: a nemzetközi közösség mindeddig csak az EJNT-ben tett kísérletet az összes emberi jog kodifikálására.

Az EJNT nem egy szokványos kódex. Eredetileg ugyan egyetlen okmányként gondolták el és kezdték szövegezni, a tervezet elkészítésében kulcsszerepet játszó Emberi Jogok Bizottsága azonban idővel úgy döntött, hogy több okmányt is kidolgoz, fenntartva azonban, hogy ezeket együttvéve tekinti majd az EJNT-nek. ${ }^{6}$ Az ENSZ Közgyűlése végül a következő okmányokat fogadta el: az Emberi Jogok Egyetemes Nyilatkozata (EJENY), a Polgári és Politikai Jogok Nemzetközi Egyezségokmánya (PPJNE), a Gazdasági, Szociális és Kulturális Jogok Nemzetközi Egyezségokmánya (GSZKJNE), valamint a PPJNE-hez tartozó fakultatív jegyzőkönyvek.

Az, hogy az EJNT-t több okmány alkotja, önmagában véve is megnehezíti a jogértelmezést, s még inkább bonyolítja a helyzetet néhány további körülmény. Először is, ezekben az okmányokban az ENSZ nem egy, hanem két kísérletet tett az összes emberi jog kodifikálására: az egyiket az EJENY-ben, a másikat a PPJNE-ben és a GSZKJNEben úgy, hogy az ezekben elismert jogok egybe számítandók. Másodszor: a jogok két listája nagyrészt átfedi egymást, de azért vannak eltérések is: egyes jogokat, amelyeket az EJENY nem ismer el, elismeri a PPJNE vagy a GSZKJNE és fordítva. Harmadszor: míg az EJENY rövid meghatározásokat ad az egyes jogokról, a két egyezségokmány általában részletesebben definiál, $\mathrm{s}$ bár a rövidebb és a hosszabb definíciók tartalma általában egybecseng, eltérések is vannak közöttük. Negyedszer: az EJENY mint közgyủlési határozat a tagállamokat nem köti, viszont mind a PPJNE, mind pedig a GSZKJNE kötelező nemzetközi szerződés. Ebből fakadóan - ötödször -, míg az EJENY-nek gyakorlatilag nincs, a PPJNE-nek és a GSZKJNE-nek van egy-egy sajátos, a részes államokat érintő végrehajtási mechanizmusa, s egy-egy ehhez kapcsolódó

5 Manfred Nowak: U.N. Covenant on Civil and Political Rights: CCPR Commentary. Kehl am Rhein, Engel, 2005. XIX.

6 UN Doc. A/2929 I. fej. 6. bek. 
értelmezése, a PPJNE esetében pedig egy esetjoga is. ${ }^{7}$ Végül, bizonyos állásfoglalások szerint az EJENY is rendelkezik jogi kötőerővel. ${ }^{8}$

Akárhogy is, az EJNT-t alkotó okmányok között van egy szoros fogalmi és kodifikációtörténeti kapcsolat, s ezért a PPJNE és a GSZKJNE értelmezésekor nem lehet eltekinteni az EJENY-től: a legkevesebb, hogy a PPJNE és a GSZKJNE előkészítő anyagának egy különleges részét kell látni benne. Mindenesetre egy olyan tanulmány, amely az emberi jogok univerzális nemzetközi jogában elismert jogoknak egy új tipológiáját kívánja felvázolni és igazolni, bizonyosan hibázna, ha elemzéséből kihagyná az EJNT-t alkotó három fő okmány bármelyikét, s nem vizsgálná ezek átfedéseit és eltéréseit.

Az EJNT a pozitív jog része, de különleges része, mivel abban a meggyőződésben fogant, hogy olyan íratlan jogokat foglal írásba és ismer el, amelyek bármiféle emberi jogalkotástól függetlenül is megilletnek minden embert. Ennélfogva, bár az új tipológia is elsősorban a pozitív jog egy részének, az EJNT-ben elismert jogoknak a tipológiája, de annyiban, amennyiben az EJNT valóban az íratlan emberi jogokat foglalja írásba, egyben az íratlan emberi jogok tipológiája is. Az EJNT-nek, $\mathrm{s}$ az EJNT-ben elismert jogok ezen új tipológiájának e duális, ugyanakkor aszimmetrikus jellege a tanulmány felépítése szempontjából is lényeges. Ennek fényében ugyanis nyilvánvaló, hogy a tanulmánynak a pozitív jog értelmezésével kell kezdenie, s innen kell haladnia az egyre inkább elméleti jellegü kérdések felé.

A tanulmány nagyrészt az EJNT-t alkotó fó okmányokat értelmezi: elemzi azokat a rendelkezéseiket, amelyek szerint az okmányok csak területhez nem kötött jogokat ismernek el, majd kimutatja, hogy az okmányok elismernek számos részben vagy egészben területhez kötött jogot is. Ezek után levezeti az új tipológia logikai-matematikai alapját, $\mathrm{s}$ rámutat, hogy az EJNT-nek azok a rendelkezései, amelyek szerint az EJNT csak területhez nem kötött jogokat ismer el, logikai-matematikai szempontból elhibázottak, majd képet ad arról, hogy milyen arányokban ismer el az EJNT területhez nem kötött és részben vagy egészben területhez kötött jogokat, és hogy mitől függ, hogy egy jog melyik területi típusba tartozik. A tanulmány ezt követően amellett érvel, hogy az új tipológia összeegyeztethető mind az emberi jogok forrásával, mind a háromszoros egyetemesség tételével, $\mathrm{s}$ végül kitér az új tipológia jelentőségére.

A tanulmányban viszonylag kevés az irodalmi hivatkozás. Ennek fó oka az, hogy tudomásom szerint az emberi jogok területi tagolódásáról mások még nem írtak. Mindazonáltal az EJNT azon rendelkezéseinek, amelyeken a területi tipológia nyugszik, már van egy nagyrészt letisztult értelmezése, amivel persze egybe kell vetni a te-

7 A fő ok, amiért a Közgyủlés úgy döntött, hogy ne egy, hanem két egyezségokmány készüljön az volt, hogy a polgári és politikai jogokat „törvényi” jogoknak, a gazdasági, szociális és kulturális jogokat „program” jogoknak tekintették, s úgy vélték, a jogok e két típusához más végrehajtási eszközök szükségesek. A/2929 I. fej. 21, 32. és II. fej. 4-12. bek.

8 Proclamation of Teheran, 2. bek. (UN Doc. A/Conf.32/41); Montreal Statement of the Assembly for Human Rights. Journal of the International Commission of Jurists, 9. (1968), 1. 95; Kardos Gábor: A nemzetközi emberi jog diszkrét bája. Fundamentum, 2. (1998), 4. 8. 
rületi tipológiát. A letisztult, uralkodó értelmezés rendszerint azonos az ENSZ Emberi Jogi Bizottságának (EJB) nézetével, a tanulmány ezért elsősorban ezt és a PPJNE kommentárjait hivatkozza.

\section{Az EJNT egyes rendelkezései szerint nincsenek területhez kötött jogok az EJNT-ben}

Vegyük először a PPJNE 2. cikkének (1) bekezdését:

„Az Egyezségokmány minden egyes részes állama kötelezi magát, hogy tiszteletben tartja és biztosítja a területén tartózkodó és joghatósága alá tartozó minden egyén számára az Egyezségokmányban elismert jogokat, minden megkülönböztetés nélkül, mint amilyen a faj, szín, nem, nyelv, vallás, politikai vagy más vélemény, nemzeti vagy társadalmi származás, vagyon, születési vagy egyéb helyzet."

E rendelkezés azon a gondolaton nyugszik, hogy a PPJNE-ben elismert jogok mindenkit megilletnek mindenhol, így minden részes államban is, ez pedig nyilván azon a gondolaton, hogy az emberi jogok megilletnek minden embert. A rendelkezés értelmében a PPJNE által elismert jogok mind területhez nem kötött jogok, s ez rögtön megkérdőjelezi az új tipológiát, hiszen a tipológia szerint a PPJNE elismer részben vagy egészben területhez kötött jogokat is.

Azt, hogy a 2. cikk (1) bekezdése értelmében a PPJNE által elismert jogok mindenkit megilletnek a részes államokban, az EJB megállapításai is alátámasztják:

„A részes államokból származó jelentések sokszor nem veszik figyelembe, hogy minden egyes részes államnak biztosítania kell az Egyezségokmányban foglalt jogokat »a területén tartózkodó és a joghatósága alá tartozó minden egyén számára « (2. cikk 1 . bekezdés)." ${ }^{10}$

„az Egyezségokmányban elismert jogok élvezete nem korlátozódik a Részes Államok állampolgáraira, hanem e jogok meg kell illessenek minden olyan egyént is állampolgárságra vagy hontalanságra tekintet nélkül, mint amilyenek a menedékkérők, menekültek, bevándorló munkások és más személyek, akik a Részes Állam területén vagy joghatósága alatt találják magukat."11

9 1976. évi 8. törvényerejű rendelet az Egyesült Nemzetek Közgyűlése XXI. ülésszakán, 1966. december 16-án elfogadott Polgári és Politikai Jogok Nemzetközi Egyezségokmánya kihirdetéséről. (A fordítást pontosítottam.)

10 HRC General Comment No. 15, The position of aliens under the Covenant, 1986. 1. bek.

11 HRC General Comment No. 31, CCPR/C/21/Rev.1/Add.13. (2004) 10. bek. 
Ami a GSZKJNE-t illeti, ebből elegendő felidézni a 2. cikk (3) bekezdését:

„A fejlődő országok, kellő figyelemmel az emberi jogokra és saját nemzetgazdaságukra, maguk határozhatják meg, hogy milyen mértékben biztosítják az Egyezségokmányban elismert gazdasági jogokat azok számára, akik nem állampolgáraik." ${ }^{12}$

Eszerint a GSZKJNE-ben elismert jogok mindenkit megilletnek minden részes államban, azaz e jogok éppúgy területhez nem kötött jogok, mint a PPJNE-ben elismert jogok a PPJNE 2. cikkének (1) bekezdése szerint. A különbség annyi, hogy a GSZKJNE 2. cikke e téren egyes részes államok számára könnyítéseket enged. Így a GSZKJNE idézett rendelkezésével sem látszik összeegyeztethetőnek az új tipológia.

A probléma vizsgálható az EJENY 2. cikke alapján is; ez így szól:

„Mindenki jogosult az e Nyilatkozatban kinyilvánított valamennyi jogra és szabadságra bármilyen megkülönböztetés nélkül, mint amilyen a faj, szín, nem, nyelv, vallás, politikai vagy bármely más vélemény, nemzeti vagy társadalmi eredet, vagyon, születés, vagy bármely más helyzet szerinti megkülönböztetés.

Ezenfelül nem lehet semmiféle megkülönböztetést tenni annak az országnak vagy területnek politikai, jogi vagy nemzetközi helyzete alapján sem, amelyhez a személy tartozik, aszerint, hogy az illető ország vagy terület független, gyámság alatt áll, nem autonóm vagy szuverenitása bármely vonatkozásban korlátozott." ${ }^{13}$

Az (1) bekezdés szerint az EJENY által elismert valamennyi jog megillet mindenkit. A rendelkezés ezt nyomatékosítja is azzal, hogy tilt bármilyen megkülönböztetést. A nevesített tilalmak ugyanakkor nem zárják ki, hogy az EJENY-ben elismert jogok között legyenek részben vagy egészben területhez kötött jogok is.

A (2) bekezdés értelmében az országok vagy területek politikai, jogi vagy nemzetközi helyzete alapján sem lehet megkülönböztetést tenni, vagyis azon az alapon sem, hogy a terület vagy ország teljesen szuverén-e vagy sem: az EJENY-ben elismert jogok ettől függetlenül is megilletnek mindenkit. Ez sem zárja ki azonban, hogy e jogok között legyenek részben vagy egészben területhez kötött jogok is.

Másfelől azonban a 2. cikk (1) bekezdése szerint „mindenki jogosult a Nyilatkozatban kinyilvánított valamennyi jogra és szabadságra bármilyen megkülönbözte-

12 1976. évi 9. törvényerejű rendelet az Egyesült Nemzetek Közgyűlése XXI. ülésszakán, 1966. december 16-án elfogadott Gazdasági, Szociális és Kulturális Jogok Nemzetközi Egyezségokmánya kihirdetéséröl.

13 Kovács István - Szabó Imre (szerk.): Az emberi jogok dokumentumokban. Budapest, Közgazdasági és Jogi, 1980. 386. Az (1) bek. fordítását javítottam; e fordítás első közlését lásd Andrássy György: Nyelvszabadság. Budapest-Pécs, Dialóg Campus, 2013. 100. 
tés nélkül”, $\mathrm{s}$ a nevesített tilalmakon túl nem lehet megkülönböztetést tenni „bármely más helyzet szerint" sem. Ebből pedig kikövetkeztethető, hogy ha vannak területhez kötött jogok, akkor annak ellenére, hogy ezek mindenkit megilletnek, egy-egy területen lesznek olyanok, akiket megilletnek, másokat meg nem, s hogy ez mégis valamilyen „helyzet szerinti” megkülönböztetés, s mint ilyen, tiltott.

A vizsgált rendelkezések közül leginkább a PPJNE 2. cikkével kapcsolatban forrta ki magát egy széles körben elfogadott nézet, amely az EJB-től származik: eszerint a 2. cikk (1) bekezdésében írt követelmény „általános szabály”, amely alól legfeljebb kivételek lehetnek. ${ }^{14}$

\section{Területhez nem kötött és részben vagy egészben területhez kötött jogok az EJNT-ben}

Az uralkodó értelmezés szerint az EJNT kizárólag vagy túlnyomórészt területhez nem kötött (egyéni) jogokat ismer el. Ennek tükrében meglepő, hogy ezt csak két jog szövege jelzi kifejezetten. Az egyik értelmében „[m]indenkinek joga van ahhoz, hogy jogalanyiságát mindenhol elismerjék”, illetve hogy „[m]indenkinek joga van arra, hogy mindenütt jogképesnek ismerjék el" (EJENY 6. és PPJNE 16. cikk), ${ }^{15}$ a másik pedig a vélemény és a kifejezés szabadságához való jog, amely mindenkit megillet „határokra tekintet nélkül” (EJENY 19 és PPJNE 19. cikk).

Attól persze, hogy az EJNT-ben elismert mintegy 40 jog közül csak kettőnek a szövege utal kifejezetten a jog területhez nem kötött jellegére, még lehet ilyen jog az EJNT-ben elismert csaknem minden jog. Bizonyosan ilyen például az élethez való jog (EJENY 3. cikk és PPJNE 6. cikk), a rabszolgaságtól és a szolgaságtól való mentességhez való jog (EJENY 4. cikk és PPJNE 8. cikk) vagy a kínzástól, a kegyetlen, embertelen, megalázó elbánástól és büntetéstől való mentességhez való jog (EJENY 5. cikk és PPJNE 8. cikk).

E tanulmány azonban azt állítja, hogy az EJNT elismer legalább 16 részben vagy egészben területhez kötött jogot is, $\mathrm{s}$ ezt alább 12 jogról ki is mutatja.

\subsection{Politikai (részvételi) jogok}

Az EJENY és a PPJNE is elismer politikai részvételi jogokat, az EJENY a 21. cikkében:

„1. Mindenkinek joga van ahhoz, hogy részt vegyen saját országa közügyeinek igazgatásában akár közvetlenül, akár választott képviselői útján.

2. Mindenkinek joga van egyenlő feltételek mellett közszolgálati állásokra való alkalmazásához a saját országában.

14 HRC General Comment No. 15, 7. és 2. bek.

15 Vö. Kovács-Szabó (szerk.) (1980): i. m. 387. és 1976. évi 8. tvr. (kiemelés - A. Gy.). 
3. A közhatalom tekintélyének alapja a nép akarata; ez az akarat időszakonként tartandó tisztességes választásokon kell hogy kifejezésre jusson egyenlő szavazati jog és titkos szavazás vagy a szavazás szabadságát ezzel egyenértékủen biztosító eljárás alapján." ${ }^{16}$

Az első két bekezdés mindenkit megillető, de mindenkit csak a saját országában vagy a saját országa tekintetében megillető jogokat, azaz területhez kötött jogokat ismer el. Más szóval mind a közügyek igazgatásában való részvétel, mind a közszolgálati állásokra való alkalmazás joga területhez kötött jog.

A (3) bekezdés szövege nem utal a saját országra, az ebben elismert jog azonban az (1) bekezdésben elismert jog egyes elemeit bontja ki, s már ezért is bizonyosra vehető, hogy ez is csak a saját országában tartandó választásokon illet meg mindenkit, vagyis hogy ez a jog is területhez kötött jog. Nézzük most a PPJNE 25. cikkét; ez így hangzik:

„Minden állampolgárnak joga és lehetősége van arra, hogy a 2. cikkben említett megkülönböztetések, illetőleg ésszerütlen korlátozások nélkül

a) a közügyek vitelében közvetlenül vagy szabadon választott képviselők útján részt vegyen;

b) szavazzon és megválasszák valódi és rendszeres választásokon, melyeket az általános és egyenlő választójog alapján titkos szavazással tartanak, biztosítva a választók akaratának szabad kifejezését;

c) az egyenlőség általános feltételei alapján közhivatali tisztséget viselhessen saját országában." ${ }^{17}$

Ez a cikk ugyanazokat a jogokat ismeri el, mint az EJENY 21. cikke, a szövegezés azonban eltérő. A különbségek közül kettő kiemelkedően fontos számunkra: az első a jogalanyokat, a második a területiség kérdését érinti.

A jogalanyokat az EJENY a "mindenki” szóval határozza meg, ${ }^{18}$ a PPJNE viszont a „minden állampolgár” kifejezéssel: az előbbi meghatározás magában foglalja az öszszes embert, az utóbbi pedig valamennyi állam valamennyi állampolgárát. Ez jelentős eltérésnek látszik, ám az EJENY 15. cikke értelmében „[m]indenkinek joga van valamely állampolgársághoz,"19 eszerint pedig minden ember állampolgár is, $\mathrm{s}$ ha így van, akkor a PPJNE „minden állampolgár” jogalany-meghatározása elvben szintén magában foglal mindenkit. A PPJNE azonban nem ismeri el a jogot az állampolgársághoz, csak azt, hogy minden gyermeknek joga van egy állampolgárság megszerzéséhez (24. cikk); ${ }^{20}$ ebből azonban, mint látni fogjuk, levezethető minden ember joga

16 Kovács-Szabó (szerk.) (1980): i. m. 290. A fordítást pontosítottam (kiemelés - A. Gy.).

17 1976. évi 8. tvr. A fordítást pontosítottam (kiemelés - A. Gy.).

18 Ez nem áll a (3) bekezdésre, amelyben csak benne rejlik egy jog.

19 Kovács-Szabó (szerk.) (1980): i. m. 389. A fordítást pontosítottam.

20 Vö. 1976. évi 8. tvr. A fordítást pontosítottam. 
egy állampolgársághoz, s így a PPJNE „minden állampolgár” meghatározása elvben szintén magában foglal mindenkit, minden embert.

A területiség kérdésében az EJENY és a PPJNE közötti különbség annyi, hogy míg az EJENY 21. cikke kettő, a PPJNE 25. cikke csak egy jogot határoz meg területhez kötött jogként. Az mindenesetre bizonyos, hogy a közhivatali tisztség viseléséhez való jog az EJENY és a PPJNE szövegezése szerint is területhez kötött jog.

Vegyük most a közügyek vitelében való részvétel jogát. Ezt az EJENY 21. cikke - mint láttuk - területhez kötött jogként határozza meg. Foglaljuk bele ezért a PPJNE 25. cikkének a) pontjába az EJENY 21. cikke (1) bekezdéséből a területhez kötöttséget jelző „saját országában” kitételt. Az eredmény ez lesz:

Minden állampolgárnak joga és lehetősége van arra, hogy a 2. cikkben említett megkülönböztetések, illetőleg észszerütlen korlátozások nélkül

a) részt vegyen a közügyek vitelében közvetlenül vagy szabadon választott képviselők útján a saját országában.

Ez teljesen észszerűnek és igazságosnak látszik, azaz úgy tűnik, hogy a közügyek vitelében való részvétel joga területhez kötött jog a PPJNE 25. cikkében is. Tegyünk azonban egy ellenpróbát: iktassunk be a PPJNE 25. cikkének a) pontjába egy olyan kitételt, amely a jog területhez nem kötött jellegére utal:

Minden állampolgárnak joga és lehetősége van arra, hogy a 2. cikkben említett megkülönböztetések, illetőleg észszerütlen korlátozások nélkül

a) részt vegyen a közügyek vitelében közvetlenül vagy szabadon választott képviselők útján minden államban.

Az eredmény ez esetben már egyáltalán nem észszerű, nem igazságos és ellentétes az államok gyakorlatával is.

A másik jog, amellyel kapcsolatban a PPJNE 25. cikke hallgat a jog területi hovatartozásáról, a választójog, s mint láttuk, hallgat erről az EJENY 21. cikke is. A választójog viszont hozzátartozik a közügyek vitelében való részvétel jogához, s mivel ez utóbbit az EJENY területhez kötött jogként ismeri el, nyilván területhez kötött jog a választójog is, s nem csupán az EJENY-ben, hanem a PPJNE-ben is. Foglaljuk tehát bele a PPJNE 25. cikke b) pontjába az EJENY 21. cikkének (1) bekezdéséből átszármaztatott utalást a saját országra. Az eredmény:

Minden állampolgárnak joga és lehetősége van arra, hogy a 2. cikkben említett megkülönböztetések, illetőleg észszerütlen korlátozások nélkül...

b) szavazzon és megválasszák a saját országában tartandó valódi és rendszeres választásokon, amelyeket az általános és egyenlő választójog alapján titkos szavazással tartanak, biztosítva a választók akaratának szabad kifejezését. 
Ez teljesen észszerủnek és igazságosnak látszik és egyezik az államok gyakorlatával is. Végezzük el azonban az ellenpróbát, azaz iktassunk be a PPJNE 25. cikkének b) pontjába egy ennek megfelelő kitételt. A szöveg ez lehet:

Minden állampolgárnak joga és lehetősége van arra, hogy a 2. cikkben említett megkülönböztetések, illetőleg észszerütlen korlátozások nélkül...

b) szavazzon és megválasszák a világ valamennyi államában az ezekben tartandó valódi és rendszeres választásokon, amelyeket az általános és egyenlő választójog alapján titkos szavazással tartanak, biztosítva a választók akaratának szabad kifejezését.

Ez a változat egyáltalán nem látszik észszerünek és igazságosnak. Nem véletlen, hogy nincs olyan állam, amely megadná a választójogot minden más ország állampolgárainak is. Nyilvánvaló tehát, hogy a választójog is területhez kötött jog, éspedig mind a PPJNE, mind pedig az EJENY szerint.

Az eddigi eredményeket két tételben lehet összegezni. Az első az, hogy az EJENY 21. cikkében és a PPJNE 25. cikkében elismert mindhárom politikai jog megillet mindenkit (EJENY), illetve minden állampolgárt, azaz a világ valamennyi államának valamennyi állampolgárát (PPJNE), minthogy azonban a PPJNE értelmében minden gyermeknek joga van egy állampolgárság megszerzéséhez, elvben mindhárom jog megillet mindenkit a PPJNE 25. cikke szerint is. A második tétel így szól: bizonyos, hogy az EJENY 21. cikkében és a PPJNE 25. cikkében elismert mindhárom politikai jog területhez kötött jog.

A gond ezek után már „csak” az, hogy e két tétel meglehetősen eltér a PPJNE 25. cikkében elismert jogok általánosan elfogadott értelmezésétől, s mivel ez lényegében az EJB véleményét tükrözi, nézzük e vélemény néhány fontos elemét:

„Az Egyezségokmány által elismert más jogokkal és szabadságokkal ellentétben (amelyek biztosíttatnak minden egyén számára az Állam területén és az Állam joghatósága alatt), a 25. cikk »minden állampolgár« jogait védi. Az országjelentéseknek vázolniuk kell azokat a jogi rendelkezéseket, amelyek meghatározzák az állampolgárságot a 25. cikk által védett jogok összefüggésében. Az állampolgárok között e jogok élvezetében nem megengedettek a különbségtételek faj, szín, nem, nyelv, vallás, politikai vagy más vélemény, nemzeti vagy társadalmi származás, tulajdon, születés vagy más helyzet alapján. A különbségtételek azok között, akiket születésüknél fogva illet meg az állampolgárság és azok között, akik honosítással szerzik ezt meg, kérdéseket vetnek fel a 25. cikkel való összhang tárgyában. Az országjelentéseknek jelezniük kell, ha bármely csoportok - mint amilyenek az állandó lakosok - élvezik e jogokat korlátozott formában, például szavazati jogot kapnak a helyi választásokon vagy betölthetnek bizonyos közszolgálati pozíciókat."21

21 HRC General Comment No. 25, The right to participate in public affairs, voting rights and the right of equal access to public service. CCPR/C/21/Rev.1/Add.7 1996, 3. bek. 
Nos, az EJB-vel szemben úgy vélem, a 25. cikkben elismert jogok nem egyszerüen kivételek a 2. cikk (1) bekezdésében foglalt követelmény alól, hanem az emberi jogoknak egy eltéró típusához tartoznak. Egyébiránt egyetértek az EJB-vel, csak hiányosnak tartom az általa adott elemzést.

Elöször is, úgy vélem, a 25. cikk jogalanymeghatározásának értelmezésekor figyelembe kell venni a PPJNE 24. cikkének (3) bekezdését, amely szerint „[m]inden gyermeknek joga van arra, hogy megszerezzen egy állampolgárságot”.22 Ebből ugyanis - mint látni fogjuk - az folyik, hogy a PPJNE hallgatólagosan elismeri minden ember jogát egy állampolgársághoz. Így viszont a 25. cikk „minden állampolgár” jogalanymeghatározása elvben kiterjed minden emberre, vagyis a cikkben elismert jogok elvben megilletnek minden embert. Az EJB elemzése azonban erről hallgat, s ezt hiányosságnak tartom.

Másodszor: az EJB szerint a 25. cikkben elismert jogok minden államban csak az állam saját állampolgárait illetik meg, más államok ott tartózkodó állampolgárait nem. ${ }^{23}$ Egyetértek, viszont hiányolom, hogy az EJB nem indokolja meg ezt az álláspontját, jóllehet ez ellentétes a 2. cikk (1) bekezdésében foglalt követelménnyel. Az EJB persze tud az ellentmondásról, hiszen másutt kimondja, hogy a 25. cikkben elismert jogok kivételt képeznek a 2. cikk (1) bekezdésében foglalt követelmény alól. ${ }^{24}$ De miért képeznek kivételt, mi erre a magyarázat? Ez az, ami hiányzik, bárhol kerül is szóba az ügy.

Harmadszor: vegyük most a 25. cikk c) pontjában elismert jogot. Ennek szövege így szól:

„Minden állampolgárnak joga és lehetősége van arra, hogy a 2. cikkben említett megkülönböztetések, illetőleg ésszerütlen korlátozások nélkül [...] c) az egyenlőség általános feltételei alapján közhivatali tisztséget viselhessen a saját országában." ${ }^{25}$

E rendelkezés nem csupán azt mondja ki, hogy minden állampolgárnak joga van közhivatali tisztség viseléséhez, hanem azt is, hogy hol van joga ehhez: minden állampolgárnak a saját országában. Ez megerősíti az EJB-nek azt az álláspontját, hogy minden (részes) államban csak az adott állam saját állampolgárait illeti meg a szóban forgó jog, más államok ott tartózkodó állampolgárait nem. Az EJB ennek ellenére említést sem tesz a rendelkezés szövegében lévő „saját országában” kitételről. Ez hiányosság, s egyben következetlenség is, ha meggondoljuk, hogy milyen kitüntetett figyelmet

22 1976. évi 8. tvr. A fordítást pontosítottam.

23 Az EJB ezt így nem mondja ki, ám ha úgy gondolná, hogy a kérdéses jogok az egyes államokban megilletik minden más állam ott tartózkodó polgárait is, akkor kérnie kellene a részes államokat, hogy jelentéseikben mutassák be, miként biztosítják e jogokat az ilyen személyeknek. Az EJB azonban ezt nem kéri.

24 HRC General Comment No. 15, 2. bek.

25 1976. évi 8. tvr. A fordítást javítottam (kiemelés - A. Gy.). 
szentel ugyanennek a kitételnek az EJB a 12. cikk (4) bekezdésében elismert jog értelmezésekor. ${ }^{26}$

Nézzük most Manfred Nowak PPJNE-kommentárját; ebben egyebek közt ez áll:

„A tényt, hogy a 25. cikk az egyetlen rendelkezés az Egyezségokmányban, amely nem egy egyetemes emberi jogot, hanem inkább egy állampolgári jogot biztosít, világosan mutatja, hogy a részes államok megtagadhatják a szavazati jogot az idegenektől. Az állampolgárra (»citoyen«, »ciudadano«) való korlátozás a modern nemzetállam fogalmából ered, nevezetesen abból, hogy csak az állampolgárság különleges kötelékével az »államukhoz« kapcsolt egyének gyakorolhatnak politikai jogokat." ${ }^{27}$

Nowak tehát úgy véli, hogy a 25. cikk „nem egy egyetemes emberi jogot, hanem inkább egy állampolgári jogot biztosít," hiszen „a részes államok megtagadhatják a szavazati jogot az idegenektől”. Véleményem szerint Nowak ott hibázik, hogy feltételezi: ha egy államban az idegeneket nem illeti meg a szavazati jog, akkor ők ki vannak zárva e jogok élvezetéből. Csakhogy mivel a szavazati jog megilleti minden állam minden állampolgárát, megilleti a részes államok területén tartózkodó idegen állampolgárságú személyeket is, persze csak az állampolgárságuk szerinti államban: nincsenek tehát kizárva a szavazati jog élvezetéből. Egyébiránt pedig az, hogy a szavazati jog minden államban csak az állam saját állampolgárait illeti-e meg, vagy megilleti más államok ott tartózkodó polgárait is, nem változtat a jogalanyok számán. A különbség nem ebben, hanem abban van, hogy hol illeti meg őket ez a jog: csak a saját államukban, vagy minden államban. Nem a ki, hanem a hol kérdéséről van tehát itt szó; nem arról, hogy minden állampolgárt megillet-e ez a jog, hiszen megilleti mindnyájukat, hanem arról, hogy hol illeti meg őket.

Állampolgársági szempontból persze idegennek számítanak egy államban a hontalanok is, s az, hogy tőlük is megtagadhatják a szavazati jogot, már érinti a jogalanyok számát, hiszen ők más államban sem rendelkeznek e joggal. Nowak álláspontja ezért velük kapcsolatban kifogástalannak látszik. Itt azonban figyelembe kell venni a PPJNE 24. cikke által minden gyermek számára elismert jogot valamely állampolgárság megszerzéséhez. Ennek folytán ugyanis mindenkinek joga van valamely állampolgársághoz, s így elméletileg senkinek sem kellene hontalannak lennie. Végső soron tehát a 25. cikk által elismert jogok, noha betű szerint csak minden állampolgár jogai, elvileg minden ember jogai.

Zárásként idézzük fel az uralkodó vélemény egyik legtömörebb összegzését a PPJNE egy másik kommentárjából:

26 HRC General Comment No. 27, Freedom of movement, CCPR/C/21/Rev.1/Add.9 1999. 1921. bek.

27 Nowak (2005): i. m. 576. 
„A 25. cikkben foglalt jogok egy-egy részes állam állampolgáraira korlátozott jogok. Ez ellentétes a PPJNE által elismert más jogokkal, amelyek megilletnek minden olyan személyt, aki egy részes állam joghatósága alá tartozik." 28

Jól látszik, hogy e kommentár szerzői is személyi korlátozásként értelmezik az itt felmerülő területi kérdést: a $k i$ kérdéseként próbálják megragadni a hol kérdését, annak ellenére is, hogy a 25. cikk c) pontja a „saját országában” kitétellel egyértelműen jelzi, hogy a hol kérdéséről van szó. A kommmentátorok azonban a kitételt még csak meg sem említik.

\subsection{Az állampolgársághoz való jog}

Az EJENY 15. cikke szerint „[m]indenkinek joga van valamely állampolgársághoz”, továbbá „[s]enkit sem lehet önkényesen megfosztani állampolgárságától és senkitől sem lehet megtagadni a jogot állampolgársága megváltoztatásához". ${ }^{29}$ Ez a jog mindenkinek biztosítja, hogy valamely államhoz tartozzon azáltal, hogy rendelkezik ennek állampolgárságával, azt azonban senkinek sem biztosítja, hogy egynél több állam állampolgára, vagy hogy valamennyi állam állampolgára legyen. Ugyanakkor minden állam olyan politikai közösség, amely önálló abban az értelemben, hogy főhatalommal rendelkezik a világ egy bizonyos területén. Ebben az összefüggésben tehát az állam területhez kötött főhatalmú politikai közösség, s ezért területhez kötött az e közösséghez tartozást kifejező állampolgárság is. Az EJENY 15. cikkében elismert jog tehát egy minden embert megillető, de területhez kötött emberi jog.

A PPJNE nem ismeri el ezt a jogot, 24. cikkének (3) bekezdésében viszont kimondja, hogy „[m]inden gyermeknek joga van arra, hogy megszerezzen egy állampolgárságot”. De vajon mi másért ismerné el a PPJNE minden gyermek számára az állampolgárság megszerzéséhez való jogot, ha nem azért, mert minden gyermeknek joga van valamely állampolgársághoz? És vajon mi másért ismerné el a PPJNE minden gyermek jogát egy állampolgársághoz, ha nem azért, mert minden embernek is joga van egy állampolgársághoz? Más szóval a szóban forgó gyermeki jog hallgatólagosan magában rejti minden ember jogát egy állampolgársághoz. ${ }^{30}$ Világos végül, hogy a PPJNE éppúgy területhez kötött jogként ismeri el az állampolgársághoz való jogot, mint az EJENY.

Az EJB nem készített általános magyarázatot az állampolgársághoz való jogról és Nowak is csak más jogok kapcsán érinti e jogot. ${ }^{31}$

28 Sarah Joseph - Jenny Schultz - Melissa Castan: The International Covenant on Civil and Political Rights, Cases, Materials, and Commentary. Oxford, Oxford University Press, 2003. 496. Vö. HRC General Comment No. 25, 3. bek.

29 A fordítást pontosítottam. Vö. Kovács-Szabó (szerk.) (1980): i. m. 389.

30 Ez egyébiránt már abból is folyik, hogy a gyermekek felnőtt korukra is megőrzik állampolgárságukat.

31 Vö. Nowak (2005): i. m. 260. 7. lábjegyzet. 


\subsection{A gyermek jogai}

Az EJENY hallgat a gyermek jogairól, e jogokat csak a PPJNE ismeri el 24. cikkében:

„1. Minden gyermeknek fajra, színre, nemre, nyelvre, vallásra, nemzeti vagy társadalmi eredetre, vagyonra, vagy születésre való tekintet nélkül joga van arra a védelemre, amely őt kiskorú állapota folytán a családja, a társadalom és az állam részéről megilleti.

2. Minden gyermeket közvetlenül születése után anyakönyvezni kell és nevet kell neki adni.

3. Minden gyermeknek joga van egy állampolgárság megszerzéséhez."32

A 24. cikk (1) bekezdése fokozott védelemhez való jogot biztosít a gyermekek számára. E védelmet a PPJNE némely más cikke is kifejezésre juttatja; ezt látjuk például az élethez való jog esetében, amennyiben a 6 . cikk (5) bekezdése kimondja, hogy „[h]alálbüntetést nem lehet kiszabni a 18. életévüket be nem töltött személyek által elkövetett büncselekmények miatt.” A 24. cikk (1) bekezdése ugyanakkor az uralkodó értelmezés szerint általános érvénnyel, a PPJNE által elismert minden jogra kiterjedően mondja ki a gyermek fokozott védelemhez való jogát. ${ }^{33}$ Ha viszont így van, akkor a gyermekeket a 24. cikk (1) bekezdésében elismert fokozott védelemhez való jog a területhez nem kötött jogok esetében területhez nem kötött, a részben vagy egészben területhez kötött jogok esetében pedig részben vagy egészben területhez kötött jogként illeti meg.

A 24. cikk (2) és (3) bekezdésében elismert jogok speciálisan gyermeki jogok. A (2) bekezdés által biztosított anyakönyvezéshez és névadáshoz való jog megillet minden gyermeket, bárhol születik is, tehát mindkét jog területhez nem kötött jog. A (3) bekezdés a gyermekeknek egy állampolgárság megszerzéséhez való jogát ismeri el. Ez a jog területhez kötött, amennyiben területhez kötött maga a megszerzendő jog is. Más kérdés, hogy a gyermeknek nem feltétlenül azon állam állampolgárságának a megszerzéséhez van joga, amely állam területén születik.

A 24. cikkben elismert jogok egy szélesebb gyermeki jog elemeiként foghatók fel, s ez az összetett jog a részben területhez kötött jogok közé tartozik.

\subsection{Mozgásszabadság}

E jogot elismeri az EJENY és a PPJNE is, és a jog a PPJNE 12. cikkének (1) bekezdése értelmében magában foglalja, hogy „[m]inden olyan személynek, aki törvényesen tartózkodik valamely állam területén, joga van e területen a szabad mozgásra és tartózkodási helye szabad megválasztására". A (2) és a (4) bekezdés ehhez hozzáteszi, hogy

32 1976. évi 8. tvr. A 3. pont fordítását javítottam.

33 HRC General Comment No. 17, Rights of the child 1-3. bek., továbbá Nowak (2005): i. m. 544-550, 560-561, valamint Joseph-Schultz-Castan (2003): i. m. 470-471. 
„[m]indenkinek szabadságában áll elhagyni bármely országot, ideértve a sajátját is”, és hogy „[s]enkit sem lehet önkényesen megfosztani attól a jogától, hogy saját országába belépjen". ${ }^{34}$

Elegendő csupán a (2) bekezdésre tekinteni ahhoz, hogy felismerjük: a mozgásszabadság magában foglal egy területhez nem kötött jogosítványt: azt, hogy mindenkinek jogában áll elhagyni minden országot. Elegendő továbbá csupán a (4) bekezdésre tekinteni ahhoz, hogy felfedezzük: a mozgásszabadság tartalmaz egy területhez kötött jogosítványt is: azt, hogy mindenkinek jogában áll belépni a saját országába, e jogától nem lehet önkényesen megfosztani. Ily módon a mozgásszabadság egy területileg vegyes emberi jog.

Osztom az EJB-nek a 12. cikk (4) bekezdésében szereplő „saját ország” kitétel értelmezésére vonatkozó megállapításait, amelyekben az EJB a többi közt leszögezi, hogy a saját országot olykor nem az állampolgárság definiálja. ${ }^{35}$ Hiányolom viszont, hogy az EJB nem mutat rá: az e bekezdésben elismert jog vagy jogosítvány és a 2. cikk (1) bekezdésében foglalt követelmény között ellentmondás van. Éppígy hiányolom, hogy az EJB nem bontja ki a „saját ország” kitételre vonatkozó okfejtésének bizonyos implikációit. Mindenekelőtt azt, hogy ha a 12. cikk (4) bekezdésében elismert jogból az következik, hogy mindenki kitüntetett kapcsolatban áll a saját országával, s így a világ egy meghatározott területével, akkor a saját országára nézve mindenkinek több emberi joga van, mint másoknak, ám ez a jogokban való különbség aligha minősülhet diszkriminációnak.

Nowak a 12. cikket kommentálva említést tesz a 2. cikk (1) bekezdéséről, s ennek kapcsán, utalva a 12. cikk (1) és (4) bekezdésére is, leszögezi: „bár formálisan jogosultak az emberi jogok élvezetére ugyanolyan módon, mint az állampolgárok, az idegeneket gyakran sújtja diszkrimináció" ${ }^{6}$ Nowak tehát úgy véli, hogy a PPJNE 12. cikkének (1) és (4) bekezdése által elismert jogok - hasonlóan a 25. cikkben elismert politikai jogokhoz - szintén kivételt képeznek a 2. cikk (1) bekezdésében foglalt szabály alól, csak ezzel most (még) kevésbé ért egyet. ${ }^{37}$ Ez ismét azt jelzi, hogy Nowak a 12. cikk (1) és (4) bekezdésének területi kitételeit személyi kérdésként fogja fel, úgy, mint tette azt a 25. cikkben foglalt politikai jogok esetében, $\mathrm{s}$ úgy vélem, itt is ebben áll érvelésének fő gyengesége.

\subsection{A menedékjog}

A menedékjogot csak az EJENY ismeri el, a PPJNE nem. Az EJENY 14. cikke kimondja, hogy „[m]indenkinek joga van az üldözés elől más országokban menedéket keresni és a más ország nyújtotta menedéket élvezni”. ${ }^{38}$ Mindenkinek joga van tehát menedék

34 1976. évi 8. tvr. A fordítást pontosítottam.

35 Vö. még például Stuart v. Canada (538/93) és Canepa v. Canada (558/93).

36 Nowak (2005): i. m. 261.

37 Nowak (2005): i. m. 261.

38 Vö. Kovács-Szabó (szerk.) (1980): i. m. 389. A fordítást pontosítottam (kiemelés - A. Gy.). 
kereséséhez „más országokban”, vagyis minden olyan országban, ahol nem üldözik. Ezért a menedékhez való jog területhez kötött jog. Megjegyzem, az ENSZ Közgyűlése 1967-ben „területi menedékjognak” nevezte ezt a jogot. ${ }^{39}$

Minthogy a PPJNE nem ismeri el a menedékjogot, az EJB erről nem készített általános magyarázatot, másutt azonban szót ejtett a menekültekről és jogaikról. ${ }^{40}$ Nowak szintén így járt el, de kitért az EJENY menedékjogról szóló cikkére is.

\subsection{Jog az önkényes számüzés elleni védelemhez}

Az EJENY elismeri ezt a jogot, a PPJNE viszont hallgat róla. Az EJENY 9. cikke kimondja: „[s]enkit sem lehet önkényesen letartóztatni, örizetbe venni vagy számüzni”. ${ }^{41}$ A cikk nem utal a jog területhez kötött jellegére, fogalmilag azonban egyértelmü, hogy valakit számüzni csak valahonnan valahová lehet, vagyis hogy az önkényes száműzés elleni védelemhez való jog területhez kötött emberi jog. Maga a latin szó, „exsilium” is jelzi ezt, mert számkivetést, idegen földön való tartózkodást és számúzetési helyet jelent, azaz a száműzés a saját országból való kiűzést jelentette és jelenti ma is. Az ókori görög és római világban a városállamok csak a saját polgáraikat számüzték. Idővel aztán Róma, majd jóval később több újkori gyarmattartó hatalom gyakran száműzte polgárait a provinciáiba, illetve a gyarmataira; ekkor a száműzés a saját országtól távoli, de a saját országtól függő területre szólt.

Az Emberi Jogok Bizottsága a PPJNE szövegezésekor is elfogadott egy rendelkezést az önkényes száműzés elleni jogról; ${ }^{42}$ ez lett a PPJNE tervezetének 11. cikke, amely szinte megismételte az EJENY 9. cikkének vonatkozó részét: „Senkit sem lehet önkényes száműzetésnek alávetni." ${ }^{{ }^{3}} \mathrm{E}$ rendelkezést azonban később törölték, „mivel az állampolgárok számüzésének büntetése már nem létezik a legtöbb államban”, egyébiránt pedig „próbálták elkerülni, hogy olyan benyomást keltsenek, hogy a nemzetközi jog elismeri a nem önkényes számüzés eseteit”."4 Mindazonáltal „a száműzés teljes tilalmának szószólói nem uralták még az Emberi Jogok Bizottságát sem, mert néhány állam még alkalmazta ezt a büntetést, $\mathrm{s}$ ezt humánusabbnak tartották, mint egy hosszú börtönbüntetést".45

Végül kompromisszum született: a PPJNE 12. cikkének (4) bekezdésébe beillesztették az „önkényesen” szót, s így ez nem nyújt abszolút jogosultságot a saját országba való belépéshez: „[s]enkit sem lehet önkényesen megfosztani attól a jogától, hogy

39 UN Doc. A/RES/2312(XXII).

40 HRC General Comment No. 27, 19. bek. és HRC: General Comment No. 31, 10. bek.

41 Vö. Kovács-Szabó (szerk.) (1980): i. m. 387. (kiemelés - A. Gy.)

42 Nowak (2005): i. m. 262.

43 Nowak (2005): i. m. 283.

44 Nowak (2005): i. m. 283.

45 Nowak (2005): i. m. 283. Az EJB szerint viszont kétséges, hogy észszerủ lehet-e egyáltalán a jog megtagadása. HRC General Comment No. 27, 21. bekezdés. A Dominikai Köztársaság időszaki jelentését értékelve az EJB még tovább ment: leszögezte, hogy „a száműzés büntetése nem egyeztethető össze az Egyezségokmánnyal". UN Doc. CCPR/C/790/Add. 18, 6. bek. Lásd még JosephSchultz-Castan (2003): i. m. 259-267. 
saját országába belépjen”. Ennek kapcsán Nowak rámutat, hogy a 12. cikk (4) bekezdésében „a szó, »önkényesen « (arbitraiment), kizárólag csak a bűncselekmény elkövetéséért büntetésként kiszabott törvényes számüzés eseteire vonatkozik, akár társul hozzá az állampolgárság megvonása, akár nem".46

Mindezek után kijelenthető, hogy a PPJNE elvben hasonló védelmet nyújt az önkényes száműzés ellen, mint az EJENY, csak míg az EJENY nyíltan elismeri, a PPJNE csak hallgatólagosan ismeri el ezt a jogot, amely - mint láttuk - területhez kötött jog.

Mivel a PPJNE nem ismeri el kifejezett módon az önkényes száműzés elleni védelem jogát, az EJB nem készített erről általános magyarázatot, sőt nem tett említést e jogról a PPJNE 12. cikkéről szóló általános magyarázatában sem.

\subsection{A külföldiek joga az önkényes kiutasítás elleni védelemhez}

Az EJENY hallgat e jogról, a PPJNE viszont elismeri 13. cikkében:

„Az Egyezségokmányban részes valamely állam területén jogosan tartózkodó külföldit csak a törvénynek megfelelően hozott határozat alapján lehet kiutasítani, és feltéve, hogy kényszerítő állambiztonsági okok nem szólnak ellene, lehetővé kell tenni számára, hogy előterjeszthesse azokat az érveket, amelyek a kiutasítása ellen szólnak és azt, hogy ügyét az illetékes hatóság vagy e hatóság által külön ere a célra kijelölt egy vagy több személy felülvizsgálja, és az eljárásban képviseltethesse magát." ${ }^{47}$

Kiinduló tézisem az, hogy a cikk jogalany-meghatározása nem szerencsés. Az ok: az EJNT a jogalanyokat rendszerint a „mindenki”, „minden személy” stb. szavakkal vagy kifejezésekkel határozza meg, vagyis oly módon, hogy a meghatározás nyilvánvalóvá teszi, hogy a jogok mindenkit megilletnek, személyileg egyetemesek. Ez az egyetemesség a 13. cikk esetében nem nyilvánvaló, jóllehet mindenkit megillet a 13. cikkben foglalt jog is, de mindenkit csak azokban az államokban, ahol külföldinek minősül (s ahol tartózkodása jogszerü). Ennélfogva a 13. cikkben elismert jog egy mindenkit megillető, de területhez kötött emberi jog.

Az EJB szerint a 13. cikkben elismert jog „csak a külföldiekre vonatkozik”, az állampolgárokra nem. ${ }^{48} \mathrm{Az}$ EJB azonban itt az egyes részes államok felöl közelít a cikkhez, s innen nézve a jog valóban csak a külföldiekre vonatkozik, a részes állam állampolgáraira nem, vagyis a jog egy személyileg korlátozott jognak látszik. Csakhogy a 13. cikkben elismert jog megilleti az egyes részes államok állampolgárait is, csak nem az állampolgárságuk szerinti államban, hanem azokban az államokban, amelyekben külföldinek számítanak (ha ott jogszerüen tartózkodnak). Ily módon a 13. cikkben elismert jog valóban egy mindenkit megillető, s egyben területhez kötött emberi jog.

46 Nowak (2005): i. m. 283. (kiemelés - A. Gy.)

47 1976. évi 8. tvr.

48 HRC General Comment No. 15, 2. bek. 
De miért nem alkalmazható a részes államokban a 13. cikk által elismert jog a részes állam állampolgáraira? A válaszhoz jó támpontot nyújt Nowak következő megállapítása: a PPJNE „nem tartalmazza az állampolgárok kiutasításának kifejezett tilalmát, de a belépéshez való jog közvetve maga után vonja ezt”. ${ }^{49}$ Nowak nyilván a 12 . cikk (4) bekezdésére utal, amely szerint „[s]enkit sem lehet önkényesen megfosztani attól a jogától, hogy saját országába belépjen" és úgy gondolja, hogy egy ország állampolgárai számára ez az ország bizonyosan az ő saját országuk. Egyetértek, és úgy vélem, ebből valóban az következik, hogy senkit sem lehet kiutasítani a saját országából.

Ezek után a 13. cikkben foglalt jog teljesebb tartalmát egy bevett jogalanymeghatározással talán így lehet megfogalmazni a legegyszerủbben:

1. Senkit sem lehet kiutasítani a saját országából és senkit sem lehet kiutasítani a 2. bekezdésben foglaltak betartása nélkül egyetlen más államból sem, ha ott törvényesen tartózkodik.

2. Az Egyezségokmányban részes valamely állam területén jogosan tartózkodó külföldit/idegent csak a törvénynek megfelelően hozott határozat alapján lehet kiutasítani, és feltéve, hogy kényszerítő állambiztonsági okok nem szólnak ellene, lehetővé kell tenni számára, hogy előterjeszthesse azokat az érveket, amelyek a kiutasítása ellen szólnak és azt, hogy ügyét az illetékes hatóság vagy e hatóság által külön ere a célra kijelölt egy vagy több személy felülvizsgálja, és az eljárásban képviseltethesse magát.

\subsection{Nyelvszabadság}

Az EJNT nem ismeri el kifejezett módon a nyelvszabadságot, ez azonban levezethető az EJNT-ben elismert egyes jogokból, s a levezetést elvégezte az EJB is, csak az eredményt nem nevezte meg. Alább az EJB levezetésének felidézésére szorítkozom, s ugyancsak az EJB álláspontjából kiindulva vetem fel a hivatalos nyelvi jogok problémáját, ${ }^{50}$ a megoldás lépései közül pedig csak a legszükségesebbeket emelem ki.

Az EJB levezetése két kanadai beadvány nyomán született meg. A panaszosok azt állították, hogy a kanadai hatóságok megsértették a PPJNE egyes cikkeiben elismert jogaikat azzal, hogy jogellenesnek minősítették saját nyelvük (az angol) használatát üzleti tevékenységük egyes területein. Az EJB részben igazat adott a panaszosoknak: kimondta, hogy sérült a PPJNE 19. cikkének (2) bekezdésében biztosított joguk a kifejezés szabadságához. A 19. cikk (2) bekezdése így szól:

„Mindenkinek joga van a kifejezés szabadságához; ez a jog magában foglalja mindenkinek azt a szabadságát, hogy keressen, megismerjen és terjesszen bármifé-

49 Nowak (2005): i. m. 283.

50 Megjegyzem, e probléma kapcsán ismertem fel egykor, hogy az EJNT elismer területhez kötött jogokat is, s e felfedezésből nőtt ki az emberi jogok e tanulmányban adott tipológiája. 
le adatot és gondolatot határokra tekintet nélkül akár szóban, akár írásban vagy nyomtatásban, vagy bármilyen más, tetszése szerinti módon." ${ }^{1}$

A kifejezés szabadságához eszerint mindenkinek joga van szóban és írásban is, ez viszont nyelvhasználattal jár. De mely nyelven vagy nyelveken van joga mindenkinek e szabadsághoz? Az EJB válasza: „Egy állam hivatalos nyelvvé választhat egy vagy több nyelvet, de nem tagadhatja meg - a közélet szféráin kívül - az egyén szabadságát önmaga kifejezésére a maga által választott nyelven." ${ }^{52}$ Az EJB tehát úgy véli, hogy a 19. cikk értelmében minden egyénnek joga van megválasztani, hogy mely nyelven gyakorolja kifejezési szabadságát. Ez viszont azt jelenti, hogy a kifejezés szabadsága magában foglalja a nyelvválasztás szabadságát, azaz a nyelvszabadságot. Minthogy pedig a kifejezés szabadsága „határokra tekintet nélkül” mindenhol megillet mindenkit, mindenhol megillet mindenkit a nyelvszabadság is; más szóval a nyelvszabadság területhez nem kötött emberi jog.

Az EJB idézett megállapítása értelmében a nyelvszabadság mindenkit megillet abban a körben, amelyre a kifejezési szabadság kiterjed, kivéve mégis a közélet szféráit. Ennélfogva a kifejezési szabadságban rejlő nyelvszabadság magánéleti szabadság..$^{53}$

Az EJB megállapításából levezethető az is, hogy miért nem terjed ki a nyelvszabadság a „közélet szféráira”. Nos, azért, mert e szférák már a hivatalos nyelvhasználat színterei, ${ }^{54}$ ahol föszabály szerint mindenki a hivatalos nyelvet köteles használni, $s$ a kötelezés egy és ugyanazon összefüggésben ellentéte a szabadságnak. Világos végül, hogy az EJB szerint azt, hogy hány hivatalos nyelve legyen egy országnak, s hogy mely nyelv(ek) legyen(ek) ez(ek), az állam jogosult meghatározni. Mi több, az EJB megállapítása azt sugallja, hogy az államokat ebben nem köti semmi, tetszés szerint dönthetnek. Csakhogy az EJB a nem megkülönböztetésről szóló általános magyarázatában (PPJNE 2. és 26. cikk) kimondja:

„A Bizottság véleménye szerint a 26. cikk nem csupán megkettőzi a 2. cikkben már szavatolt jogot, hanem egy önálló jogról rendelkezik: tiltja a jogi és a tényleges megkülönböztetést bármely, a kormányzat által szabályozott vagy védett területen., ${ }^{55}$

A 26. cikk tiltja a megkülönböztetést nyelvi alapon is, s mivel megkülönböztetés nem csupán jogok, hanem kötelességek kapcsán is érhet bárkit, a tilalom kiterjed a (részes) államok azon jogi szabályozására és gyakorlatára is, amely meghatározza, hogy hány

51 1976. évi 8. tvr. A fordítást pontosítottam.

52 Ballantyne, Davidson, McIntyre v. Canada, 358/1989. és 385/1989. 11.4. bek.

53 A kifejezési szabadság a 19. cikk (3) bekezdése szerint korlátozható, s így korlátozható a nyelvszabadság is. Az EJB szerint a hatóságok előírhatják például, hogy a „hirdetések legyenek francia és angol nyelvűek". Ballantyne, Davidson, McIntyre v. Canada, 358/1989. és 385/1989. 11.4. bek.

54 Föl lehet persze vetni, hogy egyes országoknak nincs is hivatalos nyelvük, s így az EJB megállapítása nem érvényes minden államra. Az igazság viszont az, hogy minden országnak van legalább egy hivatalos nyelve. Vö. Andrássy (2013): i. m. 160. HRC General Comment No. 18, 12. bek. 
nyelven és mely nyelven vagy nyelveken müködik államgépezetük, azaz hogy hány hivatalos nyelvük van, s mely nyelv(ek) ez(ek). Az EJB idézett álláspontja értelmében tehát a PPJNE-nek van szabálya arra nézve, hogy az államoknak hány hivatalos nyelvük legyen, s hogy mely nyelv(ek) legyen(ek) ez(ek), s ez a szabály korlátozza az államok mozgásterét: választásaik nem lehetnek megkülönböztetők.

Azt, hogy a részes államok miként tehetnek eleget a szóban forgó nem megkülönböztetési követelménynek, az EJB még nem vizsgálta meg mélyrehatóan, $\mathrm{s}$ a kommentátorok túlnyomó többsége sem bocsátkozott ilyen vizsgálódásokba. Fernand de Varennes viszont megtette ezt, és véleményét így összegezte:

„Az államgépezetnek egy vagy legfeljebb néhány nyelven kell müködnie legtöbb kapcsolata, ténykedése és szolgáltatási tevékenysége során, ami lehetetlenné teszi, hogy ne tegyen különbséget a nyelvek között. Ez megkülönböztetést (distinction) teremt: az, hogy az állam egyetlen nyelvre korlátozza magát, eltérő vagy megkülönböztető bánásmódot von maga után [...] Ez egy elkerülhetetlen helyzet, mivel egyetlen államnak sincsenek erőforrásai ahhoz, hogy az általa nyújtott minden szolgáltatást a területén beszélt összes nyelven biztosítsa." ${ }^{56}$

De Varennes tehát úgy véli, hogy a hivatalos nyelvvel kapcsolatban nem lehetséges a megkülönböztetés kiküszöbölése, ez pedig azt jelenti, hogy az EJB által meghatározott nem megkülönböztetési követelmény teljesíthetetlen. Ez igen súlyos megállapítás. Nehezen érthető, sőt nyugtalanító ezért, hogy a jogirodalomban a téma elhanyagolt: még az olyan megoldások keresésének sincs sok jele, amelyek diszkriminálnak, de csak kisebb mértékben. ${ }^{57}$

Megjegyzem, évtizedekkel ezelött lezajlott egy elméleti eszmecsere a hivatalos nyelv problémájáról, igaz, kevés jogász résztvevővel és nem szorosan a PPJNE-hez kötődve, s ez a diskurzus szintén „pesszimizmustól visszhangzott”.58 A résztvevők szerint ugyanis „[e]gy olyan megoldás, amely azonos bánásmódban részesíti minden nyelv minden beszélőjét", csak két módon lehetséges: vagy úgy, hogy az egyes államokban hivatalos nyelvvé teszik az államban saját nyelvként beszélt összes nyelvet, vagy pedig úgy, hogy egy teljesen idegen nyelvet tesznek hivatalos nyelvvé, ám a résztvevők egyik megoldást sem tartották kivihetőnek..$^{59}$

Vegyük az első megoldást és tegyük fel a kérdést: miért szükséges a hivatalos nyelvvel kapcsolatos megkülönböztetés kiküszöböléséhez, hogy minden állam tegye hivatalos nyelvvé az állam területén saját nyelvként beszélt valamennyi nyelvet? Nyilván azért, mert ekkor az ország területén élő/tartózkodó minden ember nyelve hivatalos

56 Fernand de Varennes: Language, Minorities and Human Rights. The Hague, Martinus Nijhoff, 1996. 80, 88.

57 Kompromisszumos javaslatok azért születtek és de Varennes is vázolta elgondolásait. Vö. de Varennes (1996): i. m. 77-128.

58 Jonathan Pool: The Official Language Problem. American Political Science Review, 85. (1991), 2. 495-496.

59 Pool (1991): i. m. 495-496. 
nyelv lenne, s ezek az emberek így egyenlő bánásmódban részesülnének, mindenféle megkülönböztetés nélkül: a szabályozás ugyan mindnyájukat kötelezné, hogy a hivatalos nyelvhasználat színterein valamely hivatalos nyelvet használják, de lehetővé tenné mindannyiuknak, hogy a saját nyelvüket válasszák, $\mathrm{s}$ használják hivatalos nyelvként. Ez pedig azért elengedhetetlen, mert a nyelvi alapon való megkülönböztetés esetében a kérdés az, hogy megkülönböztetés ér-e valakit a saját nyelve miatt vagy sem (és ez az, amiért a másik megoldás, hogy tegyenek egy teljesen idegen nyelvet hivatalos nyelvvé minden országban, már a diszkriminációs tilalom miatt is felvet problémákat).

Mint láttuk, a hivatalos nyelv kötelez, fogalmánál fogva kötelezettséget ír elő. Tegyük most ehhez hozzá, hogy amire a jog kötelez, annak megtételére fel is jogosít. Ha tehát a hivatalos nyelv főszabályként azt a kötelességet rója mindenkire, hogy a hivatalos nyelvet használja a hivatalos nyelvhasználat színterein, akkor azt a jogot is biztosítja mindenki számára, hogy a hivatalos nyelvet használja mindezeken a színtereken. Ily módon a hivatalos nyelv nem csupán kötelességet foglal magában, hanem jogot is: hivatalos nyelvi jogot.

Az, hogy vannak hivatalos nyelvi jogok, másképp is kimutatható. Vegyük például a PPJNE 14. cikke (1) bekezdésének első két mondatát:

„A bíróság előtt mindenki egyenlő. Mindenkinek joga van ahhoz, hogy az ellene emelt bármely vádat, vagy valamely perben jogait és kötelességeit a törvény által felállított független és pártatlan bíróság igazságos és nyilvános tárgyaláson bírálja el." ${ }^{\prime 60}$

Mindenkinek joga van tehát ahhoz, hogy az ellene emelt vádat vagy perben jogait és kötelességeit bíróság bírálja el, éspedig tárgyaláson. Egy tárgyalás azonban nyelvhasználattal jár, s ez kitűnik a 14. cikk (3) bekezdéséből is. Eszerint ugyanis „[a]z ellene emelt vád elbírálásakor mindenkinek teljes és egyenlő joga van" például ahhoz, hogy „díjmentesen vehessen igénybe tolmácsot, amennyiben nem érti vagy nem beszéli a bíróságon használt nyelvet". A bíróságon használt nyelv viszont aligha lehet más, mint egy hivatalos nyelv.

A bíróságon használt hivatalos nyelvvel kapcsolatban viszont nem csupán az a kérdés, hogy büntetőügyben mi történjen akkor, ha a vádlott nem érti vagy nem beszéli a bíróságon használt nyelvet. Fel kell tenni azt a kérdést is - éppúgy, mint a Ballantyne-ügyben a 19. cikk (2) bekezdése kapcsán -, hogy mely nyelven van joguk a jogalanyoknak a szóban forgó jog gyakorlására? És mint láttuk, a 19. cikket illetően az EJB meg is adta a választ: kimondta, hogy a kifejezés szabadságának a 19. cikk (2) bekezdésében elismert joga magában foglalja - a közélet szféráin kívül - „az egyén szabadságát önmaga kifejezésére a maga által választott nyelven". Ha viszont a 19. cikk (2) bekezdése magában foglalja hallgatólagosan a keresett nyelvi jogot vagy jogosultságot, akkor nyilván magában foglalja hallgatólagosan a 14. cikk is, csak ezt az EJB még nem hozta felszínre. De mi lehet ez a jog?

60 1976. évi 8. tvr. 
Egyetértve de Varennes-nek és a korábbi vita résztvevőinek azzal a véleményével, hogy a hivatalos nyelvvel kapcsolatos megkülönböztetés kiküszöböléséhez az szükséges, hogy váljék minden ember nyelve hivatalos nyelvvé, e jogot szerintem így lehet megfogalmazni: mindenkinek joga van ahhoz, hogy a saját nyelvét hivatalos nyelvként is használja, s hogy ezért saját nyelve hivatalos nyelv legyen. Ha azonban ezt a jogot területhez nem kötött jogként fogjuk fel, vagyis úgy, hogy mindenkit megillet mindenhol, akkor végső soron minden országban hivatalos nyelvvé kellene tenni a világon saját nyelvként beszélt összes nyelvet. Jelenleg 7000 ilyen nyelv van, ezért országonként ennyi, de legalább 800-1000 nyelvet kellene hivatalos nyelvvé tenni, ami viszont irracionális és igazságtalan, és a mai körülmények között talán kivihetetlen is volna.

Láttuk azonban, hogy a PPJNE (és tágabban az EJNT) elismer területhez kötött jogokat is, amelyek mindenkit megilletnek, de nem minden országban vagy országra nézve. És mivel a hivatalos nyelvvel összefüggő jogok irracionálisak és igazságtalanok, ha területhez nem kötött jogokként fogjuk fel őket, arra kell következtetnünk, hogy e jogok területhez kötött jogok: mindenkit megilletnek, de csak egy-egy országban. Ebben az esetben, mivel az országok száma 200 körül van, sok államnak már olyan kevés nyelvet kellene hivatalos nyelvvé tennie, hogy ez már észszerü, igazságos és kivihető is volna. Persze a nyelvek elterjedése, száma és összetétele az egyes országokban nagy eltéréseket mutat, s ezért továbbra is lennének olyan országok, amelyekben túl sok, akár 100 nyelvet is hivatalos nyelvvé kellene tenni. E problémát azonban nagyrészt megoldaná - és még mindig elvi engedmények nélkül - a hivatalos nyelv intézményében rejlő rugalmasság: nem szükséges például minden nyelvet egy ország minden térségére nézve hivatalos nyelvvé tenni. A még ezek után is fennmaradó problémákra az EJB következő megállapítása alapján kellene megoldást keresni: „Nem minden eltérő bánásmód képez diszkriminációt, ha a különbségtétel ismérvei észszerủek és objektívek és a szándék egy olyan cél elérése, amely az Egyezségokmány alapján legitim." ${ }^{61}$ Mindent egybevetve, a hivatalos nyelv problémája megoldhatónak látszik, ha a hivatalos nyelvi jogokat területhez kötött jogokként fogjuk fel.

Kérdés persze, hogy kinek-kinek hol van joga a saját nyelve hivatalos nyelvként való használatához, s ahhoz, hogy a saját nyelve hivatalos nyelv legyen? A válaszhoz több úton is el lehet jutni, de alább csak egyet járok be: azt, amelynek kezdőpontját az EJNT előkészítő anyaga, $\mathrm{s}$ ily módon az ENSZ tagállamainak jogfelfogása és gyakorlata képezi.

Már az EJENY szövegezésekor nagy vita folyt a nyelvi jogokról, főként kisebbségi összefüggésekben. De Athayde (Brazília) például kijelentette, hogy „[h]a a külföldiek használhatnák a nyelvüket az iskolákban, a bíróságok előtt és egyéb más helyzetekben, a bevándorlóknak nem állna érdekükben portugálul tanulni és mielőbb asszimilálódni a brazil népességbe”.62 Watt (Ausztrália) megállapította, hogy „[a]z európai országok a kisebbségek védelmének garantálásában érdekeltek és méltán; ez a probléma azonban ismeretlen Ausztráliában és a latin-amerikai országokban,

61 HRC General Comment No. 18, 13. bek. (kiemelés - A. Gy.).

62 A/C.3/SR.161, 721. (A fordítást lásd Andrássy [2013]: i. m. 317.) 
ahol a dolog az asszimilációról és nem a kisebbségek védelméről szól”, majd leszögezte, hogy „Ausztrália nem fogja lehetővé tenni a nemzeti nyelven kívül egyetlen más nyelv használatát sem a bíróság előtt alapvető jogként”.63 Dehousse (Belgium) ugyanakkor rámutatott, hogy „[a] kisebbségi probléma [...] különbözik a bevándorlástól: a bevándorló egy külföldi országban telepszik le és természetesen alá kell vetnie magát az öt befogadó ország törvényeinek; a kisebbségek azonban történelmileg kialakult csoportok, amelyek egy vagy több meghatározott területen élnek". ${ }^{64}$ A vitát végül Davies brit küldött így összegezte: „Amint az Egyesült Államok képviselője találóan megjegyezte, nem volt lehetséges egyetlen cikkben kompromisszumra jutni az Újvilág és az Óvilág nézetei között, mert az Újvilág asszimilálni akarja a bevándorlókat, az Óvilágban pedig faji kisebbségek léteznek." ${ }^{65}$

Mindebből nemcsak az tűnik ki, hogy a delegátusok eltérő véleményeket képviseltek, hanem az is, hogy azért volt közöttük egy jelentős háttéregyetértés is: abban, hogy a kisebbségek védelme Európában kívánatos, tekintve, hogy Európának „faji”, jobban mondva „történelmi” kisebbségei vannak, a világnak azokon a részein viszont, ahol bevándorlók alkotják a kisebbségeket, nem indokolt ilyen védelmet biztosítani. Jól látszik továbbá, hogy mind a véleménykülönbség, mind pedig az egyetértés főként a nyelvi jogokkal, s különösképp a kisebbségi nyelvek hivatalos ügyekben való használatához, valamint a kisebbségi nyelven történő oktatáshoz való joggal kapcsolatban állt fenn.

Ha azonban a delegátusok egyetértettek abban, hogy a bevándorlóknak és leszármazottjaiknak nincs joguk saját nyelvük használatához a bíróságok és más hatóságok előtt, és nincs joguk a saját nyelvü iskoláztatáshoz sem új hazájukban, akkor még kevésbé támogathatták volna, hogy tegyék a bevándorlók nyelvét hivatalos nyelvvé új hazájukban, s ily módon ismerjék el a bevándorlóknak és leszármazottjaiknak azt a jogát, hogy saját nyelvüket hivatalos nyelvként (is) használják új hazájukban. Ezzel összhangban sem az Óvilág, sem az Újvilág államai nem tették és ma sem teszik hivatalos nyelvvé a bevándorlók nyelveit: egy vagy több hivatalos nyelvüket a területükön régtől fogva, hagyományosan beszélt nyelvek, azaz a honos nyelvek közül választják ki. ${ }^{66}$

A következtetés önként adódik: a legtöbb embernek abban az országban van joga saját nyelve hivatalos nyelvként való használatához és ahhoz, hogy a saját nyelve hivatalos nyelv legyen, ahol saját nyelve honos nyelv és ahol ő maga is honos személy, vagyis a honos nyelvet beszélö közösséghez tartozva él vagy másutt él ugyan, például bevándorlóként, de e közösségből származik és - nyelvszabadságát gyakorolva - nem váltott nyelvet. Ugyanakkor azokat a személyeket, akik bevándorlóként vagy bevándorlók leszármazottjaiként élnek új hazájukban és ők vagy felmenőik - nyelvszabadságukat gyakorolva - nyelvet váltottak, itt, új hazájukban illetik meg a hivatalos nyelvi jogok

63 A/C.3/SR.161, 725-726. (A fordítást lásd Andrássy [2013]: i. m. 326.)

64 A/C.3/SR.161, 724-725. (kiemelés - A. Gy.) (A fordítást lásd Andrássy [2013]: i. m. 325.)

65 A/C.3/SR.162, 731. (A fordítást lásd Andrássy [2013]: i. m. 336).

66 A gyarmati múlt ezt valamelyest módosítja, az alapbeállítottságot azonban nem változtatja meg. 
(feltéve, hogy új nyelvük itt honos nyelv) ${ }^{67}$ Végül a történelmi kisebbségekhez tartozó személyeket abban az országban illetik meg a hivatalos nyelvi jogok, amelyhez szülőföldjük tartozik, hiszen ők itt honos személyek; ez rendkívül fontos a határon túl élő magyarság szempontjából is. A honos kisebbségi nyelvek nagy száma miatt persze némely országokban problémák adódhatnának, de - mint fentebb már szóltunk róla - e nehézségek egy bizonyos sorrendiséget betartva, elháríthatók.

A nyelvszabadság és a hivatalos nyelvi jogok között szoros összefüggés van, és az összefüggés döntő eleme a saját nyelv: a hivatalos nyelvi jogok eleve a saját nyelvre vonatkoznak. Alapvető azonban a saját nyelv szerepe a nyelvszabadságban is: a fő elem e magánéleti szabadságban is az, hogy mindenkinek joga van a saját nyelve használatához, amelyhez képest kisebb jelentőségü, hogy persze joga van mindenkinek más nyelv vagy nyelvek használatához is. A saját nyelv kitüntetett szerepét mutatja a nyelvszabadságban foglalt legerősebb jog is: a saját nyelv megtartásához és megváltoztatásához való jog. Következésképpen a nyelvszabadságnak van egy tágabb fogalma, amely magában foglalja a hivatalos nyelvi jogokat is. Minthogy pedig a magánéleti nyelvszabadság területhez nem kötött jog, a hivatalos nyelvi jogok viszont területhez kötött jogok, a tágabb értelemben vett nyelvszabadság a részben területhez kötött jogok közé tartozik.

\subsection{A lelkiismeret és a vallás szabadsága}

Ezt a szabadságot elismeri - a gondolat szabadságával együtt - az EJENY és a PPJNE is, a PPJNE 18. cikke a következőképpen:

„1. Mindenkinek joga van a gondolat, a lelkiismeret és a vallás szabadságához. Ez a jog magában foglalja mindenki szabadságát arra, hogy választása szerinti vallása vagy meggyőződése legyen, vagy hogy ilyen vallást vagy meggyőződést elfogadjon, s magában foglalja azt a szabadságot, hogy vallását vagy meggyőződését egyénileg vagy másokkal közösségben, nyilvánosan vagy magánkörben kinyilvánítsa istentisztelet, szertartás, gyakorlás vagy tanítás útján.

2. Senkit sem lehet olyan kényszernek alávetni, mely csorbítaná azt a szabadságát, hogy választása szerinti vallása vagy meggyőződése legyen, vagy hogy ilyent elfogadjon.

3. A meggyőződés kinyilvánításának szabadságát csak a törvényben megállapított olyan korlátozásoknak lehet alávetni, amelyek a közbiztonság, a rend, a közegészség, az erkölcs, vagy mások alapvető jogai és szabadságai védelmének érdekében szükségesek.

67 Andrássy György: A nyelvszabadság és a hivatalos nyelvek. In Koltay András - Török Bernát (szerk.): Sajtószabadság és médiajog a 21. század elején. 3. Complex Wolters Kluwer, 2016. 46-50. 
4. Az Egyezségokmány részes államai kötelezik magukat a szülők és adott esetben a törvényes gyámok ama szabadságának tiszteletben tartására, hogy gyermekeik vallásos és erkölcsi nevelését saját meggyőződésüknek megfelelően biztosítsák.”68

Ennek értelmében a lelkiismereti és vallásszabadság részjogosítványai túlnyomórészt a magánélet szféráira terjednek ki, ennyiben tehát ez a szabadság magánéleti szabadság. Észszerünek és igazságosnak látszik továbbá, ha e szabadság mindenkit megillet mindenhol, minden államban, s észszerűtlennek és igazságtalannak, ha mindenkit csak egy vagy csak bizonyos államokban: ebből következően a lelkiismereti és vallásszabadság területhez nem kötött jognak tekintendő.

Mindazonáltal a lelkiismeret és a vallás szabadsága szorosan összefügg bizonyos állami, kormányzati, közéleti intézményekkel, illetve szférákkal. Ennek legszembetűnőbb jele, ha egy országban valamely vallás az államvallás vagy „intézményesített” (established $)^{69}$ vallás jogállásával rendelkezik, vagy ha hagyományos vagy többségi vallásnak számít. Az ilyen tények az EJB szerint nagy figyelmet érdemelnek, s „nem eredményezhetik az Egyezségokmányban elismert egyetlen jog élvezetének csorbítását sem, ideértve a 18. és a 27. cikket is, s nem eredményezhetnek semmiféle diszkriminációt sem más vallások követőivel vagy a nem-hívőkkel szemben”70 Az EJB főként olyan intézkedésekre gondol, amelyek esetleg „az uralkodó vallás tagjaira korlátozzák a kormányzati szolgálatra való jogosultságot vagy gazdasági kiváltságokat nyújtanak számukra vagy különleges korlátozásokat vetnek ki más hitek gyakorlására [...]”, ezek ugyanis „nem felelnek meg a vallás vagy hit alapján történő diszkrimináció tilalmának és a 26. cikk által nyújtott egyenlő védelem biztosítékának".71 Az EJB számol azzal is, ha „egy hitkészletet hivatalos ideológiaként kezelnek”, s ennek kapcsán kimondja, hogy ez nem eredményezheti „a 18. cikkben elismert szabadságok semminemű megsértését vagy az Egyezségokmányban elismert bármely más jog bármilyen megsértését, sem pedig azoknak a személyeknek bármiféle diszkriminálását, akik nem fogadják el a hivatalos ideológiát vagy ellenzik azt" ${ }^{72}$

Az EJB úgy véli továbbá, hogy a 18. cikk (1) bekezdése „megengedi az állami vagy nyilvános iskolai oktatást olyan tárgyakban, mint amilyen a vallások és az etika általános története, ha ez semleges és objektív módon történik". A szülőknek és gyámoknak a 18. cikk (4) bekezdésében biztosított joga az EJB szerint „a 18.cikk (1) bekezdése által kimondott biztosítékokkal kapcsolatos, amely egy adott vallás vagy hit tanításának szabadságára vonatkozik”. Az EJB végül megjegyzi, hogy „az olyan közoktatás, amelyhez hozzátartozik egy adott vallásban vagy hitben való oktatás, nincs összhangban

68 1976. évi 8. tvr. A fordítást pontosítottam.

69 Vö. Paczolay Péter: A lelkiismereti és vallásszabadság. In Halmai Gábor - Tóth Gábor Attila (szerk.): Emberi jogok. Budapest, Osiris, 2003. 532-533, 561-562.

70 General Comment No. 22, 9. bek.

71 General Comment No. 22, 9. bek.

72 General Comment No. 22, 10. bek. 
a 18. cikk (4) bekezdésével, hacsak nem nyújt nem megkülönböztető kivételeket vagy olyan alternatívákat, amelyek megfelelnek a szülők vagy a gyámok kívánságának"73

Mindazonáltal az államvallás, intézményesített vallás stb. (és persze az intézményesített nem vallásos meggyőződés) léte problematikusabb, mint amilyennek az EJB elemzése alapján látszik. Azoknak a személyeknek ugyanis, akiknek a saját vallása azonos az államvallással vagy ezek egyikével, joguk van ahhoz, hogy saját vallásukban mint államvallásban higgyenek, s hogy saját vallásukat államvallásként gyakorolják, míg azoknak, akiknek a saját vallása nem azonos az államvallással vagy ezek egyikével, ilyen jogaik nincsenek. Érzékelte ezt valamiképp már Luther Márton is, aki megoldásként a cuius regio, eius religio elvét javasolta. Ennek az augsburgi vallásbékében történt elfogadása után a Német-római Birodalomnak két államvallása lett, a római katolikus és az evangélikus, és bizonyos előkelőségek választhattak e kettő között. Két évtizeddel később Erdélyben már négyre emelkedett az egyenjogú vallások száma, a 19. században pedig a magyar jog megteremtette a bevett vallások koordinációs rendszerét, amely együttes államvallásokká tette a bevett vallásokat, amelyek száma már hatra nőtt. ${ }^{74} \mathrm{Az}$ egyenjogúsító szabályozásnak ez az iránya más országokban, például Svájcban és Finnországban is kitapintható. Időközben viszont egy másik törekvés is egyre inkább éreztette hatását: ez az állam és a vallás, illetve az állam és az egyház elválasztására irányult, $\mathrm{s}$ ennek hátterében is a vallási egyenjogúság megteremtésének gondolata állt.

Ezek után nem nehéz észrevenni a hasonlóságot a hivatalos nyelv vagy államnyelv, valamint az államvallás között. Éppily világos, hogy mind az államnyelv intézményéből fakadó nyelvi jogegyenlőtlenség és megkülönböztetés, mind pedig az államvallás intézményéből fakadó vallási jogegyenlőtlenség és megkülönböztetés kiküszöbölését kétféle úton tartották elképzelhetőnek. Az elsőt abban látták, hogy államnyelvvé, illetve államvallássá kell tenni az egyes országokban minden ott beszélt nyelvet vagy ott követett vallást. A második út már nem volt azonos: míg az államvallás esetében a vallás állami jellegének eltörlésére törekedtek, az államnyelv esetében egy teljesen idegen nyelv hivatalossá tételének gondolatát vetették fel, nyilván abból kiindulva, hogy egy állam létezhet államvallás nélkül, de aligha létezhet államnyelv, illetve a hivatalos nyelv intézménye nélkül. Tegyük hozzá: a vallás és az egyház esetében az államtalanítást, s nem az államvallások és az államegyházak számának szaporítását ítélték alkalmasabbnak, s így az elválasztás vált uralkodó tendenciává a vallási és egyházi egyenjogúság elérésére irányuló törekvésekben.

Mindazonáltal idővel kiderült, hogy az állam és a vallás, s az állam és az egyház szétválasztása nem is olyan egyszerü, és hogy még azokban az országokban is, ahol

73 General Comment No. 22, 6. bek.

74 Az országban persze még így is voltak más vallások, ezeket a korabeli magyar jog külön fogalmak alá sorolta és külön jogállással ruházta fel: az elismert vallás (például a baptista), az el nem ismert vallás (például a nazarénus), s végül a felekezeten kívüli vallás (a valamely felekezetből kilépett vallási csoport) jogállásával. Vö. Csizmadia Andor et al.: Magyar állam-és jogtörténet. Budapest, Nemzeti Tankönyvkiadó, 2003; Magyar Katolikus Lexikon: bevett vallás szócikk. 
következetesen vitték ezt végbe, maradtak kérdések, amelyekre máig nem sikerült kifogástalan választ találni. E kérdések fóként az állami és a vallási ünnepekkel, a hivatalos munkaszüneti napokkal, az időszámítással, az egyházi intézmények, különösen az egyházi iskolák állami támogatásával, valamint a közoktatás vallási és világnézeti semlegességével kapcsolatosak. ${ }^{75}$

A probléma szerintem az, hogy a szétválasztás után egyeseket még mindig megilletnek bizonyos kiváltságok: joguk van ahhoz, hogy saját vallásuk ünnepeinek egy részét hivatalos állami ünnepként is ünnepeljék, hogy vallásuk pihenőnapját állami pihenőnapként is élvezzék, s hogy saját vallásuk időszámítását hivatalos időszámításként is használják. Ezen pedig - ahogy én látom - nem változtat az sem, ha a kérdéses napokat, ünnepeket és időszámítást a társadalom nagy többsége is magáénak érzi, a nem vallásos emberek is, vagy ha olyan új állami ünnepeket és munkaszüneti napokat vezetnek be, amelyek egyetlen vallásnak sem ünnepei és pihenőnapjai, s az időszámítást is megváltoztatják úgy, hogy az már ne kötődjön egyetlen valláshoz sem. ${ }^{76}$ (Az utóbbi megoldás akaratlanul is előnyben részesítené a nem vallásos meggyőződéseket).

A közoktatás szférájában a nehézséget az okozza, hogy az iskola műveltségi, kulturális ismereteket is közvetít és nevel is, ám mind a műveltségi, kulturális ismereteket, mind a nevelést, különösen az erkölcsi nevelést átszövik a vallási-világnézeti elemek. Ahhoz tehát, hogy a közoktatás vallási-világnézeti szempontból egyenlő jogokat biztosítson, mentes legyen a megkülönböztetéstől, s így semleges legyen, vagy ki kellene iktatni az ismeretekből és a nevelésből a szóban forgó elemeket, ami észszerűtlennek és lehetetlennek is látszik, vagy minden vallás és világnézet számára egyenlő megjelenést kellene biztosítani, amely szintén észszerütlennek és lehetetlennek látszik, hiszen az emberiség ma több ezer vallást követ.

Mindazonáltal az eddigi elemzés mögött mindvégig meghúzódott, de kimondatlan maradt egy előfeltevés: az, hogy az állami, kormányzati, közéleti szférákkal összefüggő vallási-világnézeti jogok mindenhol megilletnek mindenkit, azaz éppúgy területhez nem kötött jogok, mint a magánéleti vallás- és lelkiismereti szabadság. Kiderült azonban, hogy ilyen előfeltevés mellett e jogok sértik a vallási-lelkiismereti jogegyenlőséget, diszkriminálnak, s e problémák kiküszöbölése aligha lehetséges, s ha mégis, akkor csak észszerütlen és szinte kivihetetlen megoldásokkal. Következésképpen az állami, közéleti szférákat érintő vallási-lelkiismereti jogokat területhez kötött jogoknak kell tekintenünk. Ekkor az állami ünnepekkel, a pihenőnappal és az időszámítással kapcsolatos jogok már nem, vagy jóval kevésbé megkülönböztetők, hiszen nagyságrendekkel kevesebb vallással kell számolni, s a közoktatáson belüli ismeretközvetítés és nevelés körében is nagyságrendekkel kevesebb vallási és erkölcsi tanítás (egyenlő) megjelenítését kell csak biztosítani. A még fennmaradó problémák megoldásához

75 Schanda Balázs: A gondolat, a lelkiismeret és a vallás szabadsága. Ijoten, 2018. szeptember 14; Koltay András: $A$ vallások, az állam és a szólás szabadsága. Budapest, Századvég, 2016; Paczolay (2003): i. m. 543, 549-552, 558-575.

76 Paczolay (2003): i. m. 550-551; 10/1993. (II. 27.) AB határozat, ABH 1993. 
ki lehet aknázni a rendszerben rejlő rugalmasságot, s ha még ez is kevés, akkor az EJB már idézett tézise az irányadó: „[n]em minden eltérő bánásmód képez diszkriminációt, ha a különbségtétel ismérvei észszerüek és objektívek és a szándék egy olyan cél elérése, amely az Egyezségokmány alapján legitim."’77

De kinek-kinek hol van joga ahhoz, hogy élvezze a közélet szférájában megmaradó vallási-lelkiismereti jogokat? Nos, a jelek itt is arra utalnak, hogy a legtöbb embernek abban az országban van joga ezek élvezetéhez, ahol saját vallása honos vallás, és ahol ő maga is honos személy, vagyis a honos vallást vagy ezek egyikét követő közösséghez tartozva él vagy másutt él ugyan bevándorlóként, de e közösségből származik és - vallásszabadságát gyakorolva - nem változtatta meg vallását. Ugyanakkor azokat a személyeket, akik bevándorlóként vagy bevándorlók leszármazottjaiként élnek új hazájukban és ők maguk vagy felmenőik - élve vallásszabadságukkal - megváltoztatták vallásukat, itt, új hazájukban illetik meg a tárgyalt jogok, feltéve, hogy új vallásuk itt honos.

A lelkiismereti és vallásszabadság és az állami, kormányzati, közéleti szférákat érintő vallási-lelkiismereti jogok között szoros összefüggés van. Az összefüggés döntő eleme a saját vallás, s ez jól látszik a PPJNE 18. cikkének szövegezéséből, s éppily jól látszik az állami, kormányzati, közéleti szférákat érintő vallási-lelkiismereti jogok általam adott meghatározásából is. A saját vallás kitüntetett szerepét jelzi továbbá a lelkiismereti és vallásszabadságban foglalt legerősebb jog: a saját vallás vagy nem vallásos meggyőződés megtartásának és megváltoztatásának joga. Mindezek nyomán világos, hogy a lelkiismereti és vallásszabadságnak van egy tágabb fogalma, amely magában foglalja az állami, kormányzati, közéleti szférákat érintő vallási-lelkiismereti jogokat is. Minthogy pedig a magánéleti vallásszabadság területhez nem kötött jog, a közélet szféráit érintő vallási-világnézeti jogok viszont területhez kötött jogok, a tágabb értelemben vett lelkiismereti és vallásszabadság a részben területhez kötött jogok közé tartozik.

\subsection{Kultúraszabadság}

Az EJNT nem ismeri el kifejezetten a kultúraszabadságot, ez azonban levezethető az EJNT-ben elismert egyes jogokból. Bár a GSZKJNE kulturális jogokról is rendelkezik és az ENSZ Gazdasági, szociális és kulturális jogi bizottsága (GSZKJB) a 15. cikk (1) bekezdése által elismert jogot - azaz mindenki jogát arra, hogy részt vegyen a kulturális életben - szabadságjogként értelmezi, alább mégis inkább a PPJNE-re támaszkodom. Vegyük tehát a PPJNE 27. cikkét, amely szintén elismer egy kulturális jogot egy vallási és egy nyelvi jog mellett. A cikk szövege a következő:

„Azokban az államokban, amelyekben etnikai, vallási vagy nyelvi kisebbségek léteznek, az ilyen kisebbségekhez tartozó személyektől nem lehet megtagadni azt 
a jogot, hogy csoportjuk más tagjaival közösségben saját kultúrájukat élvezzék, hogy saját vallásukat vallják és gyakorolják, vagy hogy saját nyelvüket használják." ${ }^{78}$

Az EJB a cikkről készített általános magyarázatában egyebek közt leszögezte:

„A Bizottság megjegyzi, hogy ez a cikk olyan jogot mond ki és ismer el, amelyben kisebbségi csoportokhoz tartozó személyek részesülnek, és amely különbözik minden más, az Egyezségokmány értelmében őket mint egyéneket mindenki mással együtt megillető jogtól és kiegészíti e jogokat."79

Az, hogy egy egyezménybe felvett jog hozzátesz valamit az egyezményhez magától értetődőnek látszik: mi értelme volna egyébként annak, hogy fölvegyék az egyezménybe? Akkor viszont miért kell ezt az EJB-nek a 27. cikk kapcsán kiemelnie? Nos, a közvetlen ok az, hogy egyes részes államok a 27. cikkben elismert jogok tartalmát besorolták más, a PPJNE-ben elismert jogok alá, azaz kétségbe vonták, hogy e jogok hozzátesznek valamit a PPJNE-hez. ${ }^{80}$ Az EJB megállapítása mögött azonban ott áll Francesco Capotortinak a 27. cikk végrehajtásáról különleges jelentéstevőként készített tanulmánya is még 1977-ből. Ebben Capotorti rámutatott, hogy a cikkben elismert jogok többet jelentenek, mint amit kimondanak, vagyis vannak fontos vonzataik, implikációik és ezeket maradéktalanul ki kellene bontani, s e célból az ENSZ-nek el kellene fogadnia egy kisebbségi nyilatkozatot. ${ }^{81}$ Capotorti érveinek súlyát jelzi, hogy a nyilatkozat szövegezése hamarosan megkezdődött, s a nyilatkozatot el is fogadták, igaz, erre azért várni kellett 15 évet.

Hogy mire is jött rá Capotorti, s hogy követői, köztük Patrick Thornberry miként domborították ki még jobban az eredeti felismerést, azt a 27. cikkben elismert vallási jog kapcsán lehet a legkönnyebben kimutatni. A lényeg a következő: a 27. cikk értelmében a vallási kisebbségekhez tartozó személyeknek joguk van „saját vallásuk vallásához és gyakorlásához", csakhogy ezt a jogot a 18. cikk, amely a gondolat, a lelkiismeret és a vallás szabadságáról szól már elismeri minden ember számára, így a vallási kisebbségekhez tartozó személyek számára is. Ennélfogva a 27. cikkben elismert vallási jog „nem tesz hozzá semmit” a PPJNE-hez, vagyis „felesleges". ${ }^{82}$ Ahhoz tehát, hogy a 27. cikkben elismert vallási jog hozzátegyen valamit a PPJNE-hez, azaz hogy ne legyen „felesleges”, többet kell nyújtania, mint amit a 18. cikk nyújt, ez pedig csak úgy lehetséges, ha többet jelent, mint amit kimond, sőt többet jelent, mint amit a 18. cikk kimond, és ami a 18. cikkből következik. S így kell ennek lennie akkor is, ha a 27. és a 18. cikk szövegének egybevetése alapján ez meglepőnek látszik.

78 1976. évi 8. tvr. A fordítást pontosítottam.

79 General Comment No. 23, 1. bek.

80 General Comment No. 23, 2-4. bek.

81 Francesco Capotorti: Study on the Rights of Persons Belonging to Ethnic, Religious and Linguistic Minorities. New York, United Nations, 1979. iv, 227, 429, 617. bek.

82 Patrick Thornberry: International Law and the Rights of Minorities. Oxford, Clarendon, 1991. 180, 193. 
A fentiek szerint a 27. cikk uralkodó, az EJB által is osztott értelmezése egy implikációs vagy vonzatos jogértelmezés. Ebben nincs semmi különös: a jogászok már az ókorban tudták, hogy a jog több annál, mint amit kimond, hogy tehát különféle következtetések, implikációk bonthatók ki belőle. A baj a PPJNE 27. cikkével kapcsolatban az, hogy azt a „többet”, amit az e cikk által elismert három jognak nyújtania kell a PPJNE-ben elismert minden más egyéni joghoz képest, még sem Capotorti, sem az ENSZ kisebbségi nyilatkozata, sem e nyilatkozat kommentárja, sem az EJB, sem más nem bontotta még ki a szükséges mértékben. A magunk részéről a fentiekben e „többől” kibontottuk - igaz, nem magából a 27. cikkből ${ }^{83}$ - a tág értelemben vett nyelvszabadságot és vallásszabadságot, alább kibontjuk a tágan értelmezett kultúraszabadságot, a következő pontban pedig körvonalazzuk a kisebbségi jogokat is.

A 27. cikkben elismert kulturális jog kapcsán az első kérdés az, hogy ennek vajon mely jognál kell többet nyújtania a PPJNE által elismert más egyéni jogok közül? A legfontosabb ilyen jogot már Thornberry megjelölte:

„A lényeg itt az, hogy ha a 27. cikknek nem tulajdonítunk erősebb tartalmat, ez nem tesz hozzá semmit az Egyezségokmányhoz. A gondolat, a lelkiismeret és a vallás szabadságát már védi a 18 . cikk, és ott van például, amennyiben a nyelvet és a kultúrát nézzük, a kifejezés szabadságáról szóló rendelkezés a 19. cikkben is." ${ }^{84}$

Thornberry szerint tehát a 27. cikkben elismert kulturális jognak - hasonlóan a 27. cikkben elismert nyelvi joghoz - a 19. cikkben elismert vélemény- és kifejezési szabadságnál kell többet nyújtania. Az, hogy a 19. cikk szövege nem tartalmazza a „kultúra” szót, nem perdöntő, hiszen nem tartalmazza e szöveg a „nyelv” szót sem, az EJB mindazonáltal - mint fentebb láttuk - e szövegre támaszkodva mondta ki a Ballantyne-ügyben, hogy az államok a közélet szféráin kívül nem tagadhatják meg „az egyén szabadságát önmaga kifejezésére a maga által választott nyelven". ${ }^{85}$ Éppígy lehetséges tehát, hogy a vélemény és a kifejezés szabadsága hallgatólagosan magában foglalja a kultúra szabadságát is, csak az EJB ezt eddig még nem állapította meg. Az pedig, hogy a kifejezés szabadsága valóban tartalmazza a kultúra szabadságát, több mint valószínủ. A 19. cikkben elismert kifejezési szabadság ugyanis kiterjed bármilyen adatok és eszmék, így a kulturális adatok és eszmék keresésére, megismerésére és terjesztésére is. Nem véletlen, hogy a müvészi és a tudományos szabadságot, valamint a tanszabadságot a vélemény és a kifejezés szabadságából szokták eredeztetni. A kultúraszabadság éppígy levezethető a vélemény és a kifejezés szabadságából; annál is inkább, mert a múvészet és a tudomány (de voltaképpen az oktatás és tanulás is) a kultúra része, $\mathrm{s}$ ha van művészi, tudományos szabadság és tanszabadság is, furcsa volna, ha kulturális szabadság nem létezne.

83 A közvetlen levezetést lásd Andrássy György: A magyar nyelv jogállása, a kultúraszabadság és egyes emberi jogok területhez kötöttsége. JURA, 22. (2016), 1. 12-13 és 17-22.

84 Thornberry (1991): i. m. 180. (kiemelés - A. Gy.).

85 Ballantyne, Davidson, McIntyre v. Canada, 358/1989. és 385/1989. 11.4. bek. 
A nyelvszabadsághoz (és a vallásszabadsághoz) hasonlóan a kultúraszabadság is elsősorban magánéleti szabadság: mindenekelőtt a magánélet szféráira terjed ki. Ugyancsak hasonlóan a nyelvszabadsághoz és a vallásszabadsághoz, a kultúraszabadság is megillet mindenkit mindenhol, azaz ez is egy területhez nem kötött magánéleti szabadság.

Mindazonáltal a kultúraszabadság - hasonlóan ismét a nyelvszabadsághoz és a vallásszabadsághoz - szorosan összefügg bizonyos állami, kormányzati, közéleti szférákkal. Hivatalos kultúráról vagy államkultúráról ugyan nem szokás beszélni, de a nemzeti kultúra fogalma ismert és fontos, és az állam összefonódik bizonyos fokban egy vagy több kultúrával már csak a hivatalos nyelv és a hivatalos munkaszüneti napok, állami ünnepek révén is. Jelentős továbbá az állam kulturális örökségvédelmi tevékenysége, amely nagyrészt az állam területén hagyományosan elterjedt egy vagy több kultúra örökségének védelmére irányul. Ugyancsak jelentős a tudomány, a mủvészet, a népművészet állami támogatása, valamint az államnak az oktatásban betöltött szerepe.

Mindezek után a probléma szintén hasonló ahhoz, amit a nyelvszabadság és a vallásszabadság esetében már láttunk. Nevezetesen az, hogy azok, akiknek a saját kultúrájuk azonos az állam, a kormányzat, az állami örökségvédelem által támogatott valamely kultúrával, illetve akiknek a kultúrája azonos a közoktatásban túlsúlyba kerülö kulturális ismeretekkel és értékekkel, azoknak kimondatlanul is joguk van ahhoz, hogy saját kultúrájukat államilag támogatott kultúraként élvezzék, míg azoknak, akiknek a kultúrája nem azonos az említett kultúrák egyikével sem, nem élvezik ezt a jogot.

A PPJNE 2. és 26. cikke nem tiltja nevesítetten a megkülönböztetést kulturális alapon, ám tiltja nemzeti vagy társadalmi származás alapján, s tiltja bármilyen nem nevesített alapon is. Emellett a 26. cikk biztosítja a törvény egyenlő védelmét mindenki számára, s ez a védelem kiterjed a kultúra szférájára is. Ily módon a probléma végső soron az, hogy hogyan lehetne biztosítani az egyenlő jogvédelmet és a megkülönböztetés kiküszöbölését a kultúrának a közélettel érintkező szféráiban, hiszen a világon a kultúrák száma is ezres nagyságrendű és lehetetlennek látszik, hogy az állam mindezeket teljesen egyenlő módon támogassa, vagy hogy a közoktatásban egyenlő ismereteket nyújtson róluk és egyenlő nevelési szerepet kapcsoljon hozzájuk. Minderre - vagy az állam és a kultúra minél teljesebb szétválasztására - azonban csak akkor lenne szükség, ha az EJNT csak területhez nem kötött jogokat ismerne el. E tanulmány fó tézise viszont épp az, hogy az EJNT és ezen belül a PPJNE elismer területhez kötött emberi jogokat is. S mivel a kultúraszabadság a közélet szférájában területhez nem kötött jogként irracionálisnak és igazságtalannak látszik és talán kivihetetlen is, területhez kötött jogként viszont észszerünek, igazságosnak tűnik és kivihetőnek is, e jognak területhez kötött jognak kell lennie.

A kérdés már csak az, hogy kinek-kinek hol van joga ahhoz, hogy a közélet szférájában is élvezze a kulturális jogokat. Nos, minden jel arra utal a kulturális jogok esetében is, hogy a legtöbb embernek abban az országban van joga a közéleti jogok élvezetéhez, 
ahol saját kultúrája honos kultúra, és ahol ő maga is honos személy, vagyis a honos kultúrát vagy ezek egyikét követő közösséghez tartozva él vagy másutt él ugyan bevándorlóként, de e közösségből származik és - kultúraszabadságát gyakorolva - nem váltott kultúrát. Ugyanakkor azokat a személyeket, akik bevándorlóként vagy bevándorlók leszármazottjaiként élnek új hazájukban és ők maguk vagy felmenőik - élve kultúraszabadságukkal - kultúrát váltottak, itt, új hazájukban illetik meg a tárgyalt jogok, feltéve, hogy új kultúrájuk itt honos kultúra.

A kultúraszabadság és az állami, kormányzati, közéleti szférákat érintő kulturális jogok között szoros összefüggés van. Az összefüggés döntő eleme a saját kultúra, $\mathrm{s}$ ezt igen jól jelzi a kultúraszabadságban foglalt legerősebb jog: a saját kultúra megtartásának és megváltoztatásának joga. A következtetés innen már önként adódik: a kultúraszabadságnak van egy tágabb fogalma, amely magában foglalja az állami, kormányzati, közéleti szférákat érintő kulturális jogokat is. Minthogy pedig a magánéleti kultúraszabadság területhez nem kötött jog, a közéleti szférákat érintő kulturális jogok viszont területhez kötött jogok, a tágabb értelemben vett kultúraszabadság a részben területhez kötött jogok közé tartozik.

\subsection{Kisebbségi jogok}

Kisebbségi jogokat csak a PPJNE ismer el, az EJENY hallgat róluk. A PPJNE 27. cikke - mint már láttuk - három kisebbségi jogot ismer el: az etnikai kisebbségekhez tartozó személyek jogát saját kultúrájuk élvezéséhez, a vallási kisebbségekhez tartozó személyek jogát saját vallásuk vallásához és gyakorlásához, valamint a nyelvi kisebbségekhez tartozó személyek jogát saját nyelvük használatához. Az előző pontban láttuk azt is, hogy az EJB kimondta: az említett kisebbségekhez tartozó személyeket megillető három jog „különbözik minden más, az Egyezségokmány értelmében őket mint egyéneket mindenki mással együtt megillető jogtól és kiegészíti e jogokat". ${ }^{86}$ Láttuk végül, hogy a vallási kisebbségi jognak elsősorban a gondolat, a lelkiismeret és vallás szabadságánál (18. cikk), a nyelvi és a kulturális jognak pedig elsősorban a vélemény és a kifejezés szabadságánál (19. cikk) és e szabadságok ki nem mondott, hallgatólagos tartalmainál kell többet jelenteniük. A szóban forgó többletjelentéseket az előző három pontban nagyrészt feltártuk, amikor levezettük a magánéleti nyelvszabadságot és a magánéleti kultúraszabadságot, valamint a nyelvszabadság, a kultúraszabadság és a vallásszabadság közéleti jogosítványait, s így eljutottunk a tágabb értelemben vett nyelvszabadsághoz, vallásszabadsághoz és kultúraszabadsághoz.

Mindezek után világos, hogy a 27. cikkben elismert kulturális kisebbségi jognak immár a kultúraszabadságnál, a vallási kisebbségi jognak a vallásszabadságnál, a nyelvi kisebbségi jognak pedig a nyelvszabadságnál kell többet jelentenie. A kultúraszabadság, a vallásszabadság és a nyelvszabadság mindenkit megillető szabadságok, s mindenkit megilletnek e szabadságok közéleti jogosítványai is. Minthogy azonban 
a közéleti jogosítványok területhez kötöttek, mindenkit csak egy bizonyos területen illetnek meg: a legtöbb embert ott, ahol saját kultúrájuk, saját vallásuk vagy saját nyelvük honos. Ez az egyes országokban azt jelenti, hogy a honos kisebbségieket otthon illetik meg e jogosítványok, a bevándorló kisebbségieket és leszármazottjaikat pedig, ha nem váltottak kultúrát, vallást vagy nyelvet, származási országukban; ha váltottak, akkor honossá váltak új hazájukban, s így itt illetik meg őket e jogok.

A kisebbségi jogok alapvetően az etnikai, vallási és nyelvi többség, valamint az etnikai, vallási és nyelvi kisebbségek, illetve a hozzájuk tartozó személyek materiális, tényleges egyenlőségét hivatottak megteremteni és fenntartani, vagyis az olyan hátrányok kiküszöbölését szolgálják, amelyek a kisebbségi kultúrák, vallások és nyelvek kisebbségi helyzetéből fakadnak (kisebb személyi kör, kisebb presztízs, kisebb túlélési esélyek stb). Ennélfogva a honos etnikai, vallási és nyelvi kisebbségekhez tartozó személyeknek joguk van saját kultúrájuknak, saját vallásuknak vagy saját nyelvüknek kiemelt, a honos etnikai, vallási vagy nyelvi többség kultúrájánál, vallásánál vagy nyelvénél erősebb védelmére és támogatására. Másfelől a bevándorló kisebbségieknek, ha ők vagy felmenőik nem váltottak kultúrát, vallást és/vagy nyelvet, joguk van új hazájukba való beilleszkedésük támogatásához, mindenekelött a befogadó ország legalább egy honos és egyben hivatalos nyelve elsajátításának támogatásához, valamint az ott honos vallások és honos kultúrák bizonyos fokú megismerésének támogatásához. Ha a bevándorlók/leszármazottjaik kultúrát, vallást és/vagy nyelvet váltottak, és nem a többségi kultúra, vallás vagy nyelv, hanem egy honos kisebbségi nyelv, vallás és/vagy kultúra lett a saját kultúrájuk, saját vallásuk vagy saját nyelvük, akkor honos kisebbségiekké váltak és kisebbségi jogaik nagyrészt ehhez igazodnak.

Összegezve, az etnikai, vallási vagy nyelvi kisebbségekhez tartozó személyek kulturális, vallási vagy nyelvi jogai mindig a világ valamely részén, valamely országban illetik meg a jogalanyokat, vagyis e jogok területhez kötött jogok.

\subsection{Jog az oktatáshoz}

Az oktatáshoz való jogot elismeri az EJENY és a GSZKJNE is, és mind az EJENY, mind a GSZKJNE 13. cikkének szövege arra enged következtetni, hogy ez a jog mindenkit megillet mindenhol, azaz egy területhez nem kötött jog. Mindazonáltal e jognak egészen biztosan vannak területhez kötött jogelemei, s ezek némelyikét az előző négy pontban már érintettük is: a nyelvszabadság és a kisebbségi nyelvi jogok tárgyalásakor az oktatás nyelvének, a lelkiismereti és vallásszabadság, valamint a kisebbségi jogok tárgyalásakor az oktatás vallási és világnézeti tartalmainak ${ }^{87}$ a kultúraszabadság és a kisebbségi jogok tárgyalásakor pedig az oktatás kulturális tartalmainak kérdését.

Minthogy az oktatáshoz való jognak van területhez nem kötött és területhez kötött jogosítványa is, a széles értelemben vett jog a részben területhez kötött jogok közé tartozik.

87 Erre kitér a GSZKJB is. Vö. CESCR General Comment No. 13, 28. bek. 


\section{Az új tipológia logikai alapja és a PPJNE 2. cikke (1) bekezdésének logikai hibája}

Két fő állítást vizsgáltam az eddigiekben. Az első az volt, hogy a PPJNE, a GSZKJNE és az EJENY 2. cikkének rendelkezései arra utalnak, hogy az EJNT által elismert valamennyi emberi jog mindenkit megillet mindenhol, vagyis hogy e jogok mind területhez nem kötött jogok. A második állítás ezzel szemben úgy szólt, hogy az EJNT-ben elismert egyes jogok mindenkit megilletnek, de részben vagy egészben nem mindenhol, más szóval hogy e jogok részben vagy egészben területhez kötött emberi jogok. A fentiek szerint mindkét állítás igaz, csakhogy ellentmondanak egymásnak. A fó kérdés ezért immár az, hogy melyiket kell irányadónak tekinteni? Az eddigi elemzés értelmében azt, amely szerint az EJNT elismer részben vagy egészben területhez kötött jogokat is.

Mint láttuk, azt az EJB is megállapította, hogy nincs összhang a PPJNE 2. cikkének (1) bekezdésében foglalt követelmény és a PPJNE 25. és 13. cikkében elismert jogok között, és az EJB is arra a következtetésre jutott, hogy ezekben az esetekben nem a 2. cikk (1) bekezdése szerinti követelményt, hanem az említett jogok szövegezését kell irányadónak tekinteni. Ennyiben tehát álláspontom egyezik az EJB (és a kommentátorok) álláspontjával.

Az idegenek helyzetéről szóló általános magyarázatában az EJB átfogóan is kifejtette véleményét a PPJNE 2. cikkének (1) bekezdésében írt követelményről, s arról, hogy miként vonatkozik ez a PPJNE-ben elismert jogokra. A többi közt ezt írta:

„1. A részes államokból származó jelentések sokszor nem veszik figyelembe, hogy minden egyes részes államnak biztosítania kell az Egyezségokmányban foglalt jogokat »a területén tartózkodó és a joghatósága alá tartozó minden egyén számára « (2. cikk 1 . bekezdés). Általában véve az Egyezségokmány által kimondott jogok mindenkire alkalmazandók, függetlenül a viszonosságtól és függetlenül az egyén állampolgárságától vagy hontalanságától.

2. Az általános szabály ennélfogva az, hogy az Egyezségokmányban elismert minden egyes jogot biztosítani kell az állampolgárok és az idegenek közötti megkülönböztetés nélkül. A 2. cikk előírása szerint az idegenek megkapják a nem megkülönböztetés általános követelményének jótéteményét az Egyezségokmányban elismert jogokra vonatkozóan. Ez a biztosíték megilleti az idegeneket és az állampolgárokat egyaránt. Kivételesen néhány, az Egyezségokmányban elismert jog kifejezetten csak az állampolgárokra alkalmazható (25. cikk), míg a 13. cikk csak a külföldiekre. Mindazonáltal a Bizottságnak a jelentések vizsgálatában szerzett tapasztalata azt mutatja, hogy számos országban más jogokat, amelyeket az idegeneknek élvezniük kellene az Egyezségokmány értelmében, megtagadnak tőlük vagy olyan 
korlátozásoknak vetnek alá, amelyek nem mindig igazolhatók az Egyezségokmány alapján." 88

Egyetértek azzal, hogy a 2. cikk (1) bekezdése szerinti követelmény, valamint a 25 . és a 13. cikkben elismert jogok között ellentmondás van; egyetértek azzal is, hogy a 25. és a 13. cikk értelmezésekor e cikkek rendelkezései az irányadók, s nem a 2. cikkben írt szabály. Egyetértek végül azzal, hogy a 25 . cikkben elismert jogok az egyes részes államokban csak az adott állam állampolgárait illetik meg, a 13. cikkben foglalt jog pedig csak az ott jogszerủen tartózkodó idegeneket. Ezek lényeges egyezések, és mégis, az EJB összegzése elfedi a 25. és a 13. cikkben elismert jogok területhez kötött jellegét, s elfedi általában a PPJNE-ben elismert jogok terület szerinti tagolódását. Az alábbiakban ezért egy olyan összefüggésben folytatom az EJB elemzésének vizsgálatát, amelyben tisztán, világosan megmutatkozik a PPJNE által elismert jogok területi tagolódásának logikai, matematikai alapja, s az, hogy ennek fényében elhibázott a PPJNE 2. cikkének (1) bekezdésében írt követelmény.

Vegyük az EJB szóban forgó általános magyarázatának 7. bekezdését. Ez felsorolja azokat a jogokat, amelyek az EJB szerint megilletik az állampolgárokat és az idegeneket is a részes államokban. ${ }^{89} \mathrm{~A}$ lista a PPJNE által elismert 21 egyéni jogból ${ }^{10} 19$-et tartalmaz, s ez összhangban áll az EJB-nek azzal a nézetével, hogy a 2. cikk (1) bekezdésében foglalt követelmény „általános szabály”, ${ }^{11}$ amely alól kivételt képeznek a 25 . és a 13. cikkben elismert jogok; ezek hiányoznak is a listáról.

A felsorolásban az EJB ezt írja a mozgásszabadságról: a részes államokban az idegeneknek - a részes államok polgáraihoz hasonlóan - „joguk van a mozgás szabadságához és lakhelyük szabad megválasztáshoz; szabadságukban áll elhagyni az országot".92 Csakhogy a mozgásszabadságot elismerő 12. cikk a (4) bekezdésében elismer még egy jogot: azt, hogy „[s]enkit sem lehet önkényesen megfosztani a jogtól, hogy belépjen a saját országába". Ezt az EJB már nem foglalta bele a felsorolásba, de nem tüntette fel a 2. cikk (1) bekezdése alóli kivételek között sem; ez mindenképp hiba. Nézzük meg azonban, hogy hogyan értelmezi az EJB ezt a jogot a mozgásszabadságról szóló általános magyarázatában:

„A 12. cikk (4) bekezdésének szövegezése nem tesz különbséget állampolgárok és idegenek között (»senkit«). Ily módon azt, hogy mely személyeket illeti meg e jog gyakorlása, csak a »saját országában « kifejezés jelentésének értelmezésével lehet meghatározni. A »saját országában « fogalom kiterjedése tágabb, mint az »állampolgárságának országa« fogalomé. Nem korlátozódik az állampolgárságra

88 HRC General Comment No. 15, 1-2. bek. (kiemelés - A. Gy.).

89 HRC General Comment No. 15, 7. bek.

90 Az EJB figyelmen kívül hagyta a PPJNE 20. cikkét, amely a háborús propagandát, valamint a nemzeti, faji vagy vallási gyűlölet hirdetését tiltja.

91 HRC General Comment No. 15, 7. bek.

92 HRC General Comment No. 15, 7. bek. 
formális értelemben, vagyis a születéssel vagy adományozással megszerzett állampolgárságra; magában foglal minimálisan egy olyan egyént, akit egy adott országhoz füződő különleges kapcsolata vagy különleges igénye miatt nem lehet pusztán idegennek tekinteni." ${ }^{\prime 3}$

Az EJB tehát úgy véli, hogy egy államban az állam saját állampolgárait, valamint azokat, akiket különleges kapcsolat vagy igény füz ehhez az államhoz - köztük alkalmasint a hosszú ideje az államban élő idegeneket ${ }^{94}$ - megilleti a 12. cikk (4) bekezdésében elismert jog, a pusztán idegeneket viszont nem. Eszerint a 12. cikk (4) bekezdésében elismert jog is kivételt képez a 2. cikk (1) bekezdésében foglalt követelmény vagy „általános” szabály alól.

Csakhogy a 12. cikk (4) bekezdése szerint „senkit” sem lehet önkényesen megfosztani attól a jogtól, hogy belépjen a saját országába, s ezt - mint láttuk - az EJB is nyugtázza. Ám akkor hogyan lehetséges, hogy az egyes országokban vagy az egyes országokra nézve a pusztán idegeneket mégsem illeti meg ez a jog? Hogyan lehetséges tehát, hogy egy mindenkit megillető emberi jog, amelytől senkit sem lehet önkényesen megfosztani, az egyes országokra nézve mégsem illet meg mindenkit, mégsem illeti meg a pusztán idegeneket?

A megoldás kulcsát a 2. cikk (1) bekezdésében foglalt követelmény - vagyis hogy az Egyezségokmány minden részes állama kötelezi magát, hogy tiszteletben tartja és biztosítja a területén tartózkodó és joghatósága alá tartozó minden egyén számára az Egyezségokmányban elismert jogokat - előfeltevései képezik. A követelmény ugyanis azon az előfeltevésen nyugszik, hogy az Egyezségokmányban elismert jogok mindenkit megilletnek minden államban, ez pedig azon, hogy az emberi jogok megilletik az összes embert. Csakhogy abból, hogy egy jog mindenkit megillet, nem következik, hogy minden országban vagy minden országra nézve is megillet mindenkit. Ahhoz ugyanis, hogy egy jog mindenkit megillető jog legyen, elegendő, ha a jog mindenkit megillet valahol, mondjuk egy országban: attól, ha mindenkit megillet más országokban is, vagy akár az összes országban, a jogalanyok száma nem nő, a jogalanyok számát ez nem érinti. Nincs tehát ellentmondás abban, hogy a 12. cikk (4) bekezdésében elismert jog mindenkit megillet, viszont az egyes országokra nézve nem illet meg mindenkit. A jog szövegezése logikailag kifogástalan. A 2. cikk (1) bekezdésében foglalt követelmény viszont, mint a fentiekben bemutatott előfeltevések konklúziója, logikailag hamis.

Azzal a megállapítással, hogy a jogalanyok számát nem befolyásolja, ha egy mindenkit megillető jog mindenkit megillet mindenhol, vagy mindenkit megillet, de nem mindenhol, elérkeztünk az emberi jogok új, területi tipológiájának logikai, matematikai alapjához. Elérkeztünk tehát ahhoz a logikai, matematikai fundamentumhoz, amely nyilvánvalóvá teszi, hogy a mindenkit megillető jogok lehetnek olyanok, amelyek mindenkit megilletnek mindenhol, lehetnek továbbá olyanok, amelyek

93 HRC General Comment No. 27, 20. bek.

94 HRC General Comment No. 27, 20. bek. 
mindenkit megilletnek, de nem mindenhol, s lehetnek végül olyanok, amelyek mindenkit megilletnek részben mindenhol, részben viszont nem mindenhol, más szóval hogy a mindenkit megillető jogok lehetnek területhez nem kötött, területhez kötött és részben területhez kötött jogok. Az említett logikai-matematikai alapzat fényében tehát az, hogy a PPJNE (és tágabban az EJNT) elismer területhez nem kötött, területhez kötött és részben területhez kötött jogokat is, a legkevésbé sem problematikus.

Logikai szempontból a PPJNE által elismert területhez nem kötött, területhez kötött és területileg vegyes jogok egyenrangúak abban az értelemben, hogy egyik típus sem általános a másik kettőhöz képest. Abból ugyanis, hogy a szóban forgó jogok mindenkit megilletnek, nem következik, hogy minden vagy csaknem minden jognak az egyik jogtípushoz kell tartoznia, a másik kettőhöz pedig egynek sem vagy csak a maradéknak, más szóval hogy az egyik típusnak általánosnak kell lennie, a másik kettőnek pedig legfeljebb kivételnek. A PPJNE 2. cikkének (1) bekezdésében foglalt követelmény szerint viszont a PPJNE által elismert minden jognak mindenkit mindenhol, minden országban megillető jognak kell lennie, azaz a jogok első típusához kell tartoznia, s így e típusnak általános típusnak kell lennie. Ez viszont, mint láttuk, logikai szempontból tarthatatlan. Ki kell tehát mondani, hogy a 2. cikk (1) bekezdésében foglalt követelmény logikai szempontból nem „általános szabály”, a neki nem megfelelő jogok pedig nem „kivételek” alóla.

Egy területhez kötött jog, mint amilyen a 12. cikk (4) bekezdésében elismert jog is, mindenkit megillet, de mindenkit csak valamely területen, mondjuk egy országban vagy országra nézve. Ennek folytán minden országban vannak olyanok, akiket megillet ez a jog, de lehetnek olyanok is, akiket nem. Ez pedig megkülönböztetésnek látszik, ám nem az. Egy területhez kötött emberi jog ugyanis pusztán azon oknál fogva, hogy területhez kötött, még mindenkit megillet és mindenkit egyenlő mértékben és módon illet meg, vele kapcsolatban tehát a megkülönböztetés kizárt. Ennélfogva az, hogy egy területhez kötött emberi jog az egyes országokban némelyeket megillet, másokat meg nem, csak látszólag megkülönböztetés: valójában nem az, hiszen a jog azokat is megilleti egy másik országban, akiket itt, ebben az országban nem illet meg. Be kell tehát vezetnünk - a közvetlen és a közvetett diszkrimináció közötti különbségtételhez hasonlóan - a valódi és a látszólagos diszkrimináció fogalmát. A látszólagos diszkrimináció ugyanis feltűnhet az összes, részben vagy egészben területhez kötött emberi jog kapcsán. Arra a kérdésre tehát, hogy hogyan lehetséges, hogy egy jog szövegezése a jogalanyok meghatározásakor nem tesz különbséget idegenek és állampolgárok között, az egyes országokra nézve viszont különbséget tesz közöttük, a válasz így szól: ha a jog részben vagy egészben területhez kötött jog [és a 12. cikk (4) bekezdésében elismert jog ilyen], akkor ez úgy lehetséges, hogy a megkülönböztetés csak látszólagos. 


\section{A területhez nem kötött és a részben vagy egészben területhez kötött jogok aránya}

Az, hogy a PPJNE 2. cikkének (1) bekezdésében írt követelmény logikai szempontból nem „általános szabály”, még nem zárja ki, hogy általános szabály legyen statisztikailag, más szóval hogy a PPJNE-ben elismert jogok mindegyike vagy nagy többsége megfeleljen neki, azaz területhez nem kötött jog legyen. De ilyenek-e a PPJNE által elismert jogok?

Vegyük ismét az EJB álláspontját, de immár ebben az összefüggésben értelmezve. Mint tudjuk, az EJB általános szabálynak tartja a szóban forgó követelményt vagy szabályt, de ez alól azért említést tesz két kivételről: a 25. és a 13. cikk által elismert jogokról. Fentebb azonban láttuk, hogy az EJB valójában kivételnek tekinti a 12. cikk (4) bekezdésében elismert jogot, a saját országba való belépéshez való jogot is, amely persze eleme a mozgásszabadságnak, s így maga a mozgásszabadság képezi a harmadik kivételt az „általános szabály” alól. A fentiekben kiderült továbbá, hogy kivételt képez a 24. cikkben elismert gyermeki jog, valamint a 18. cikkben elismert vallásszabadság és a 27. cikkben elismert (három) kisebbségi jog is. A kivételek száma így hat és mind a hat a kifejezetten elismert jogok közé tartozik. Láttuk azonban, hogy a PPJNE hallgatólagosan további négy részben vagy egészben területhez kötött jogot is elismer: az állampolgársághoz, az önkényes száműzés elleni védelemhez, valamint a nyelvszabadsághoz és a kultúraszabadsághoz való jogot. A kivételek száma így már tíz.

Az EJB szerint a PPJNE 21 jogot ismer el. ${ }^{95} \mathrm{E} 21$ joghoz most hozzá kell adnunk a négy hallgatólagosan elismert jogot, $\mathrm{s}$ a kapott 25 joghoz kell mérnünk a tíz kivételt. A kivételek aránya így $40 \%, \mathrm{~s}$ ez túl magas ahhoz, hogy a szabály „általános szabály” legyen.

A kivételek száma ráadásul még nem is teljes. Az eddigi elemzés ugyanis nem terjedt ki a PPJNE-ben elismert valamennyi jogra, és úgy vélem, van a PPJNE-ben még legalább egy jog, amely a kivételekhez tartozik: a szabad társuláshoz való jog (22. cikk).

Nézzük most a polgári és politikai jogok számát az EJNT egészében. A változás egyfelől az, hogy az EJENY kifejezett módon elismer két, a PPJNE által csak hallgatólagosan elismert kivételt: az állampolgársághoz és az önkényes száműzés elleni védelemhez való jogot, másfelől pedig az, hogy az EJENY elismeri a menedék keresésének jogát is. Így az EJNT-ben elismert olyan polgári és politikai jogok száma, amelyek kivételt képeznek az általános szabály alól 12, s ezek közül 10 kifejezett módon elismert jog.

Vannak azonban az EJNT által elismert gazdasági, szociális és kulturális jogok között is olyanok, amelyek a kivételekhez tartoznak, s egyikükről, az oktatáshoz való jogról ezt ki is mutattuk. Ilyen jog azonban véleményem szerint a kulturális életben való részvétel joga, a munkához való jog, $\mathrm{s}$ az ehhez szorosan kapcsolódó jogok, de legalább kettő ezek közül. A kivételek száma így 17-re nő. Az említett kulturális jog 
viszont lényeges átfedésben van a PPJNE 27. cikkében elismert kulturális joggal, s ezért vegyük úgy, hogy csak a kifejezetten elismert kivételek számát növeli, a kivételekét nem. A kifejezetten elismert kivételek száma így 15, a kivételeké pedig legalább 16. Az EJNT mintegy 40 egyéni jogot ismer el, ennek a 16 kivétel a $40 \%$-át teszi ki, ez pedig kizárja, hogy a szabály „általános szabály” legyen.

Összegezve, a részben vagy egészben területhez kötött jogok sem logikai, sem statisztikai szempontból nem kivételek a területhez nem kötött jogok alól, az olyan jogok alól, amelyek mindenkit megilletnek minden államban. Ennek értelmében a területhez kötött és a részben területhez kötött jogok éppoly önálló jogcsoportot képeznek, mint a területhez nem kötött jogok, s ez azt jelenti, hogy e tanulmány fó állítása, miszerint az EJNT-ben elismert jogok terület szerint (is) jogcsoportra tagolódnak, igazolódott.

Kimondható-e ezek után, hogy a PPJNE, a GSZKJNE és az EJENY 2. cikkének azok a rendelkezései, amelyek szerint az ezekben az okmányokban elismert valamennyi jog mindenkit megillet minden államban, teljesen elhibázottak? Nem, véleményem szerint ezt nem lehet kimondani: úgy vélem, ezeket az elöírásokat megdönthető vélelmeknek kell tekinteni azoknak a jogoknak a szempontjából, amelyekről még nem bizonyosodott be, hogy megfelelnek-e nekik vagy sem, s ez fontos az egyezségokmányok, kivált a PPJNE alkalmazása szempontjából is.

\section{Mitől függ, hogy egy jog a területi tipológia mely jogcsoportjához tartozik?}

Korábban már láttuk, hogy az EJB a PPJNE 25. cikkében elismert jogok kapcsán arra az álláspontra helyezkedett, hogy e jogok minden részes államban csak a részes állam saját állampolgárait illetik meg, más államoknak a részes államban tartózkodó polgárait nem. Magam is egyetértettem ezzel, kifogásoltam viszont, hogy az EJB nem indokolja meg ezt az álláspontját, jóllehet ez nincs összhangban a 2. cikk (1) bekezdésében foglalt követelménnyel. Csakhogy egyelőre magam sem indokoltam meg az EJB álláspontjával egyező véleményemet kellő mértékben. Azt már levezettem, hogy a 2. cikk (1) bekezdésében foglalt követelmény mint egy következtetés eredménye logikailag hibás; azt is kimutattam, hogy a PPJNE elismer olyan jogokat is, amelyek részben vagy egészben csak egy bizonyos térségben illetnek meg mindenkit. Arra a kérdésre viszont még csak igen röviden adtam választ, hogy mitől függ, hogy egy egyéni emberi jog mely területre nézve illet meg mindenkit, vagyis hogy területhez nem kötött, területhez kötött, vagy részben területhez kötött jog-e?

E kérdésre először a PPJNE 25. cikke kapcsán adtam választ. A cikk három jogot ismer el, s ezek egyike, a közhivatali tisztségek viseléséhez való jog a cikk szövege szerint területhez kötött jog - minden állampolgárnak joga van arra, hogy „közhivatali tisztséget viselhessen saját országában" -, a másik két jog szövegében viszont nincs utalás arra, hogy hol illetik meg e jogok az állampolgárokat. Minthogy viszont az nem lehetséges, hogy egy jog sehol a világon ne illesse meg a jog alanyait, a szóban 
forgó két jognak is meg kell illetnie valahol az állampolgárokat, de hogy hol, azt már csak jogértelmezéssel lehet megállapítani. Saját jogértelmezésemhez a fentiekben készítettem egy tesztet: mivel a közhivatali tisztségek viseléséhez való jog csak a saját országukban illeti meg az állampolgárokat, beiktattam a „saját országában” kitételt a másik két jog szövegébe is és megállapítottam, hogy ezek szövegezése e kitétellel kiegészítve észszerű, igazságos és megfelel az államok gyakorlatának is. Ezután tettem egy ellenpróbát: beiktattam a két jog szövegébe azt, hogy „minden államban”, s azt találtam, hogy a jogok szövegezése így már nem észszerü, nem igazságos és nem is egyezik az államok gyakorlatával. Mindebből levontam azt a következtetést, hogy a 25. cikkben elismert mindhárom jog területhez kötött jog: e jogok megilletik a világ valamennyi állampolgárát, de mindegyiküket csak a saját országában. Alább azt fogom megindokolni, hogy miért épp az észszerűséget és az igazságosságot tekintettem fö mércének, s nem csupán a PPJNE 25. cikkében elismert jogok, hanem az EJNT által elismert minden egyéni jog esetében.

Maradjunk egyelőre a PPJNE 25. cikkénél. Az ebben elismert jogokkal kapcsolatban számos olyan kérdés merül fel, amelyekre a cikk szövege nem ad választ. Ilyen például, hogy hány éves kortól illetik meg az állampolgárokat az egyes jogok, hogy milyen alapon lehet állampolgárokat megfosztani a szavazás jogától (és milyen időre), s hogy mely választott tisztségek összeférhetetlenek például bírói hivatallal vagy katonai tisztséggel. Ezekben és más hasonló esetekben a részes államoknak kell meghatározniuk a jogok közelebbi tartalmát, illetve nekik kell dönteniük a jogok bizonyos fokú korlátozásáról. A cikk bevezető szövege nyilván erre tekintettel fekteti le a következő megkötéseket: „minden állampolgárnak joga és lehetősége van a 2. cikkben említett megkülönböztetések és ésszerütlen korlátozások nélkül arra, hogy.... Eszerint a jogok közelebbi meghatározása és korlátozása nem lehet megkülönböztető és nem lehet észszerűtlen.

Az EJB a 25. cikkről szóló általános magyarázatában kitér számos olyan pontra, ahol szükség mutatkozik a cikk által elismert jogok konkretizálására, illetve korlátozására, $\mathrm{s}$ eközben 17 alkalommal állítja az észszerüség mércéjét a részes államok idevágó szabályozása elé. De miért is kell a konkretizálásnak és a korlátozásnak annyira igazodnia az észszerűséghez, hogy már a cikk szövegének bevezető része felállítja ezt a mércét, az EJB pedig 17 esetben alkalmazza is? Nos, nyilván azért, mert már maguk a konkretizálandó és korlátozandó jogok is észszerűek, s ennélfogva a konkretizálásukra és korlátozásukra vonatkozó észszerűségi követelmény valójában csak a jogok észszerüségét hivatott fenntartani és továbbadni. Kimondható tehát, hogy a 25. cikkben elismert jogok maguk is észszerüek.

Nézzük most a 25. cikk bevezetésében lefektetett másik mércét, amely szerint a cikk által elismert jogok közelebbi meghatározása és korlátozása nem lehet megkülönböztető a 2. cikk által tiltott megkülönböztetések értelmében. Nem meglepő ezek 
után, hogy az EJB e mércére is hivatkozik a 25. cikk által elismert jogok konkretizálásával, illetve korlátozásával kapcsolatban, igaz, csak öt alkalommal. ${ }^{96}$

Ezen a ponton vessünk egy pillantást az EJB-nek a nem megkülönböztetésről készített általános magyarázatára, illetve ennek utolsó bekezdésére. Ez így hangzik: „[ne]m minden eltérő bánásmód képez diszkriminációt, ha a különbségtétel ismérvei észszerüek és objektívek és a szándék egy olyan cél elérése, amely az Egyezségokmány alapján legitim". ${ }^{97}$ Eszerint tehát lehetnek és vannak is esetek, amikor az eltérő bánásmód nem minősül diszkriminációnak, és az eltérő, a megkülönböztető bánásmód tilalma alól felmentést adó mércék között ott találjuk az észszerűséget. Ez viszont azt jelenti, hogy a nem megkülönböztetés elve bizonyos fokban maga is az észszerűségen nyugszik. ${ }^{98}$

A nem megkülönböztetés elve szoros kapcsolatban áll a törvény előtti egyenlőséggel és a törvény egyenlő védelméhez való joggal, s így bizonyos fokban ezek is az ész parancsai. Minthogy pedig a nem megkülönböztetés elve és a törvény egyenlő védelmének joga kisugárzik a PPJNE egészére, az észszerűség is áthatja a PPJNE egészét. Nem csak a PPJNE 25. cikke által elismert jogok észszerűek tehát, a többi jog is az.

Az észszerűség mércéjét tovább erősíti, hogy ez kitüntetett szerepet játszik a modern természetjog elméleti és jogalkotási hagyományában. Hobbes például a természeti törvényeket „egyetlen, könnyen érthető alapelvben” is összefoglalta:
„[A]mit nem akarsz, hogy veled megtegyenek, azt ne tedd meg mással." „Ẹ „Eből látható - folytatta Hobbes -, hogy a természeti törvények megtanulásához nem kell egyebet tennünk, mint azt, hogy amikor mások cselekedeteit a magunkéhoz mérjük, és az előbbieket túlságosan súlyosaknak találjuk, helyezzük azokat a mér- leg másik serpenyőjébe, és tegyük helyükbe a magunk cselekedeteit, hogy a saját érzelmeink és önszeretetünk semmit se nyomhasson a latba. És ekkor a természeti törvények közt egy se fog akadni, amit ne találnánk észszerünek." ${ }^{100}$

Locke a természeti törvényt egyenesen az ésszel, az „ész törvényével”, „az ész általános törvényével” azonosította, ${ }^{101}$ amely „mindenkit, aki csak hozzá fordul, megtanít arra, hogy mivel az emberek valamennyien egyenlők és függetlenek, senki sem károsíthat meg egy másik embert életében, egészségében, szabadságában vagy javaiban". ${ }^{102}$ Ily módon „a természeti törvény nyilvánvaló és érthető minden eszes teremtmény számára". ${ }^{103}$

96 Az EJB háromszor használja a „distinction” és kétszer a „discrimination” terminust. Vö. HRC General Comment No. 25.

97 HRC General Comment No. 18, 13. bek. (kiemelés - A. Gy.).

98 Lehet, hogy az elv egészen az észszerűségen nyugszik, hiszen a tilalom alóli felmentés másik két mércéje (az objektivitás és a cél legitim volta) szintén észszerüségi kívánalom.

99 Thomas Hobbes: Leviatán. Magyar Helikon, 1970. 135.

100 Hobbes (1970): i. m. 135. (kiemelés - A. Gy.).

101 John Locke: Értekezés a polgári kormányzat igazi eredetéröl, hatásköréröl és céljáról. Budapest, Gondolat, 1986. 42, 76, 50.

102 Locke (1986): i. m. 42.

103 Locke (1986): i. m. 127. (kiemelés - A. Gy.). 
Mindez persze még csak a természeti törvényről és nem a természetes jogokról szól. Minthogy azonban Hobbes felfogásában a természeti törvény a természetes szabadságot szorítja észszerủ korlátok közé, Locke szerint pedig a természetes jogok a természeti törvényből fakadnak, nyilvánvaló, hogy a természetes szabadságnak és a többi természetes jognak is észszerủnek kell lennie. Idekívánkozik végül az Amerikai Függetlenségi Nyilatkozat nevezetes tétele: „Magától értetődőnek tartjuk azokat az igazságokat, hogy minden ember egyenlőnek teremtetett, hogy Teremtőjük elidegeníthetetlen jogokkal ruházta fel őket, melyek közé tartozik a jog az élethez, a szabadsághoz, valamint a boldogságra való törekvéshez." ${ }^{104}$

Ezek után úgy tűnhet, hogy már csak alkalmazni kell az észszerüség mércéjét a PPJNE-ben, illetve az EJNT egészében elismert jogokra, és máris kiderül, melyik tartozik a területhez nem kötött, s melyik a részben vagy egészben területhez kötött jogok közé. Figyelembe kell azonban venni, hogy az EJENY, a PPJNE és a GSZKJNE is leszögezi, hogy minden ember „egyenlő és elidegeníthetetlen jogainak elismerése alkotja a szabadság, az igazságosság és a béke alapját a világon." ${ }^{105}$ Eszerint az emberi jogok nem csupán az észszerűség, hanem egyben az igazságosság kifejezői is, s így az észszerűség mellett az igazságosság teszi lehetővé (az emberi jogok felismerésén és meghatározásán túl) az egyes jogok további konkretizálását és határaik pontosabb megvonását. Az igazságosságnak persze több felfogása, elmélete, s éppígy többféle fajtája ismeretes, és kérdés, melyikük - esetleg jogcsoportonként melyikük - számít ebben az összefüggésben. Ennek vizsgálatára itt nincs tér, annyit viszont megjegyezhetek, hogy már Hobbes és Locke felfogásában is szoros a kapcsolat az észszerűség és az igazságosság között. Hobbes szerint ugyanis „az uralkodónak és legfőbb hivatalnokainak az összes tudományok közt csakis a természetes igazságosság tudományára van szükségük”, 106 Locke szerint pedig „a természeti törvény [...] az ész és a közönséges igazságosság (equity) szabálya". ${ }^{107}$

Ezen a ponton érintenem kell a tágabb elméleti keretet is. A politikafilozófia központi kérdése (vagy egyik központi kérdése) Platón óta az, hogy milyen is lenne egy eszményi vagy legalábbis jó állam, $\mathrm{s}$ hogy miként lehet az ilyen állam berendezkedését igazolni. A természeti törvény és a természetes jogok elméletei szintén e kérdés körül forgolódtak és forgolódnak, s voltaképpen válaszok e kérdésre. A terminológia persze idővel némiképp módosult: míg Platón egy ideális államról elmélkedett, Locke már inkább egy jól berendezett államról (commonwealth), John Rawls pedig egy jól berendezett társadalomról. ${ }^{108}$

Platón és aztán sokan mások, köztük a természeti törvény és a természetes jogok teoretikusai is arra a következtetésre jutottak, hogy egy politikai közösség akkor tökéletes vagy jól berendezett, ha az igazságosságra épül. Ily módon a természeti törvény

104 Vö. Kovács-Szabó (szerk.) (1980): i. m. 633.

105 Vö. a három okmány preambulumával (kiemelés - A. Gy.).

106 Hobbes (1970): i. m. 311. (kiemelés - A. Gy.).

107 Locke (1986): i. m. 46.

108 Locke (1986): i. m. 142, 145, 154; John Rawls: Az igazságosság elmélete. Budapest, Osiris, 1997. 23. 
és a természetes jogok elméletei szintén az igazságosság elméleteinek tekinthetők, bárhogy fogták is fel az egyes gondolkodók az igazságosságot. Az mindazonáltal bizonyos, hogy az igazságosság tradicionális fogalma kitűnően illeszkedik a természetjogi elméletek logikájába, s kitűnően illeszkedik az EJNT logikájába is. Az igazságosságnak arra a hagyományos fogalmára gondolok, amelyet Ulpianus úgy fogalmazott meg, hogy „suum cuique tribuere”, azaz mindenkinek megadni a magáét, azt, ami jár neki. Ez az EJNT-re alkalmazva azt jelenti, hogy az EJNT voltaképpen azokat a jogokat ismeri el minden ember számára, amelyek egyébként is megilletik őket emberi mivoltuknál, méltóságuknál fogva, s ebből következően járnak nekik a pozitív jogtól, így az EJNT-től is.

Fontos mérce tehát az észszerűség mellett az igazságosság is, $\mathrm{s}$ ez az, amiért már a 25. cikkben elismert jogok kapcsán is figyelembe vettem. Az igazságosság mércéje persze érvényes az EJNT által elismert többi jogra is: e jogok terület szerinti vizsgálata során sem csak az észszerüségre kell tehát rákérdeznünk, hanem arra is, hogy hol jár mindenkinek az adott jog vagy jogelem: mindenhol, csak valahol, vagy részben mindenhol, részben valahol.

Nehézségekbe ütközhet a mércék alkalmazása is. Lehet például, hogy valamely jog esetében nem ad egyértelmű választ sem az észszerüségi, sem az igazságossági teszt. Ilyenkor érdemes megvizsgálni, hogy elég konkrét-e a jog vagy jogelem szövegezése, hogy nem tartalmaz-e rejtetten egy területhez nem kötött és egy területhez kötött jogelemet is, ez ugyanis megmagyarázza a teszt sikertelenségét. Adódhatnak azonban más problémák is, s ezek szintén külön vizsgálódásokat igényelnek.

\section{Az emberi jogok eredete és a területi tipológia}

A PPJNE és a GSZKJNE preambuluma leszögezi, hogy az emberi jogok „az emberi személyiség veleszületett méltóságából erednek”.109 Nowak szerint „[ez] a bekezdés, mely egy ausztrál javaslaton alapul, az első bekezdéshez hasonlóan kifejezi, hogy az emberi jogok a természeti törvényből származnak és nem egyedül a nemzetközi jog általános elveiből fakadnak (mint egy jugoszláv tervezet tartalmazta az Emberi Jogok Bizottságában)" ${ }^{110}$ Nos, származzanak az emberi jogok akár a természeti törvényből, akár az emberi személyiség méltóságából, bizonyos, hogy mind a PPJNE, mind a GSZKJNE a jogi és filozófiai gondolkodás természetjogi hagyományának talaján áll. ${ }^{111}$

109 Kovács-Szabó (szerk.) (1980): i. m. 397.

110 Nowak (2005): i. m. 2. Vö. még E/CN.4/370. E/CN.4/SR.333, 7.

111 Miként John Simmons írja: „Az emberi jogok nem csupán történelmileg kötődnek a természetes jogokhoz; ők maguk természetes jogok, vagy inkább a természetes jogoknak egy megkülönböztetett és fontos osztályát képező jogok." John Simmons: Human Rights, Natural Rights, and Human Dignity. In Rowan Cruft - Matthew Liao - Massimo Renzo (szerk.): Philosophical Foundations of Human Rights. Oxford, Oxford University Press, 2015. 144-145. 
Az emberi jogok elméletében vannak kételyek a jogok eredetét illetően, ${ }^{112}$ az uralkodó vélemény azonban máig az, hogy az embereket az emberi jogok emberi mivoltuknál (emberi természetüknél, lényegüknél, méltóságuknál stb.) fogva illetik meg, s így szükségképp megilletnek minden embert. Ahogy John Simmons írja:

„Az emberi jogok, ha (a szokásos módon) egyetemes jogokként fogjuk fel őket, vagyis olyan jogokként, amelyek szükségképpen megilletnek minden emberi lényt (és csak emberi lényt), azon természetes (nem megállapodásszerű) erkölcsi jogok lennének tehát, amelyek nem csupán megillethetik, hanem meg is kell illessék az embereket, nem csak a természeti állapotban, hanem minden más »nem természetes « feltételek között. Az emberi jogoknak az emberekkel veleszületett jogoknak (vagyis az emberi élet kezdetének pillanatától élvezett jogoknak) kell lenniük, és olyan jogoknak, amelyeket nem lehet elveszíteni - elidegenítés vagy lemondás útján (vagyis önként, szándékos döntéssel), illetve elveszíteni (gondatlanságból vagy jogsértéssel) vagy elévüléssel (akár kormányzati »elévülési határozatok«, akár hosszú időn át tartó nem érvényesítés folytán)."113

Ha azonban az emberi jogok szükségképp megilletnek minden embert, s az emberek el sem veszíthetik e jogokat, akkor e jogok hozzátartoznak minden emberhez, elszakíthatatlanok tőlük, s velük vannak, bárhol tartózkodjanak is. Ezért úgy tủnik, az emberi jogok mindenkit megilletnek mindenhol, azaz eleve területhez nem kötött jogok. Ez esetben viszont hogyan ismerhet el az EJENY, a PPJNE és a GSZKJNE is jelentős számban olyan emberi jogokat, amelyek mindenkit megilletnek, de részben vagy egészben nem mindenhol? Véleményem szerint úgy, hogy a két tétel valójában kiegészíti egymást.

Induljunk ki abból, hogy a jogok, s közelebbről az egyéni jogok egyénhez, személyhez kötött jogok abban az értelemben, hogy bárhol tartózkodik is az egyén, fö szabályként vele vannak egyéni jogai is. Képtelen állapotokhoz vezetne ugyanis, ha a helyváltoztatás azzal járna, hogy az egyén elveszítené otthon hagyott személyes tárgyainak tulajdonjogát, de éppígy szülői felügyeleti jogát, külföldre utazva pedig akár az állampolgárságát is. Logikus tehát, hogy az egyéni jogokat a pozitív jog eleve egyénhez kötött jogokként fogja fel.

Az emberi jogok egyénhez kötöttsége még erősebb: e jogok ugyanis mindenkihez hozzátartoznak elválaszthatatlanul, elszakíthatatlanul és elveszíthetetlenül, s így szükségképp megilletnek minden embert mindenhol és ezt a területi jellegzetességet leképezi az emberi jogok joga is. Ezt a jellegzetességet azonban kiegészíti egy másik, amelyet így lehet megfogalmazni: „valamely területre nézve”. Láttuk ugyanis, hogy ahhoz, hogy egy jog mindenkit megillessen, logikai, matematikai szempontból nem szükséges, hogy mindenkit megillessen mindenhol, egyes jogok esetében pedig

112 Vö. például Donnelly (2003): i. m. 13-21; Charles R. Beitz: The Idea of Human Rights. Oxford, Oxford University Press, 2011. 3-7.

113 Simmons (2015): i. m. 145. 
ez igazságtalan, sőt irracionális is volna. Nem véletlen tehát, hogy az EJNT elismer részben vagy egészben területhez kötött jogokat is.

A kiegészített tézis ezek után úgy hangzik, hogy mindenkit megillet minden egyéni emberi jog mindenhol, de minden esetben valamely területre nézve: vagy a világ egész területére nézve, vagy csak a világ egy bizonyos területére nézve, vagy részben a világ egész területére, részben viszont csak egy bizonyos területére nézve. A PPJNE preambuluma, valamint 12. cikkének (4) bekezdése értelmében például mindenkinek mindenhol joga van ahhoz, hogy belépjen a saját országába, ${ }^{114}$ (s e jogát a világ minden országában tiszteletben is kell tartani), ám ez a jog mindenkit csak a világ egy meghatározott részére nézve illet meg abban az értelemben, hogy mindenkit csak a saját országába való belépésre jogosít fel, más országokba való belépésre nem.

A mondottak nyilván összefüggnek az emberi jogok (és/vagy a természeti törvény) személyi, területi és időbeli hatályával, nemkülönben az emberi jogok jogának személyi, területi és időbeli hatályával, s e kettő kapcsolatával. A kérdéskör elemzése fontos, ebből azonban már csak a háromszoros egyetemesség tézisét érinthetem.

\section{A háromszoros egyetemesség tézise és a területi tipológia}

A tézist már Cicero lefektette: mint írta, „Rómában sem lesz más törvény, s megint más Athénban, s ismét más most, majd megint más később, hanem valamennyi népet mindenkor ugyanaz az örök és változatlan törvény fogja irányítani”. ${ }^{15}$ Locke így fogalmazott: „[a] természeti törvény... örök szabály, mely mindenkire, törvényhozókra és másokra egyaránt kötelező." ${ }^{116}$ Locke itt nem említette a törvény területi egyetemességét, de bizonyos, hogy ilyenként fogta ezt fel. ${ }^{117}$

Hasonló véleményen volt az amerikai politikai gondolkodók nagy része is a 18. század második felében: Alexander Hamilton például - William Blackstone-t idézve - úgy vélte, hogy a természeti törvény „kötelező az egész világon, minden országban és minden időkben". ${ }^{118}$ E gondolkodók persze egyre nagyobb jelentőséget tulajdonítottak a természeti törvényből fakadó természetes jogoknak. Richard Bland például így írt: „[A] Természet Törvényéhez kell folyamodnunk, és az Emberiségnek azokhoz a Jogaihoz, amelyek ebből fakadnak." 119

A természeti törvényt tehát úgy fogták és fogják fel, mint amely mindenkit kötelez és jogosít mindenhol és minden időben, a természetes jogokat, s az emberi jogokat

114 A preambulum kimondja, hogy az emberi jogok az emberi lény méltóságából erednek, amiből az következik, hogy az emberi jogok elválaszthatatlanok minden embertől, vele vannak, bárhol tartózkodjék is; az emberi jogok így mindenkit megilletnek mindenhol.

115 Marcus T. Cicero: Az állam. Budapest, Akadémiai, 1995. Harmadik könyv, 22 (33).

116 Locke (1986): i. m. 135. \$.

117 Vö. Locke (1986): i. m. például 97, 100-101, 120, 128.

118 Alexander Hamilton: The Farmer Refuted. Founders Online, National Archives, 2019. 20. bek.

119 Richard Bland: An Inquiry into the Rights of the British Colonies. Idézi Craig Yirush: The Idea of Rights in the Imperial Crisis. In Ellen Frankel Paul - Jeffrey Paul - F. Miller Jr. (szerk.): Natural Rights Individualism and Progressivism in American Political Philosophy. Cambridge, Cambridge University, 2012. 89. 
pedig úgy, hogy ezek mindenkit megilletnek mindenhol és minden idökben. Mindez pedig a természeti törvény és a természetes vagy emberi jogok háromszoros egyetemességét jelzi: a személyi, a területi és az időbeli egyetemességet.

A természetjogi és az emberi jogi gondolkodás a 19. században elvesztette, a 20. század közepén azonban - annak folytán, hogy az ENSZ elkötelezte magát az emberi jogok mellett - visszanyerte uralkodó helyzetét, s ez megmutatkozik a jogok egyetemességének felfogásában is. Az EJENY szövegezésének vége felé például a Harmadik Bizottság (gyakorlatilag az ENSZ Közgyűlése) áttekintette az elkészült tervezetet, $\mathrm{s}$ „kinyilvánította minden ember egyenlőségét mindenhol”, ${ }^{120}$ ami azt is jelentette, hogy a Bizottság szerint az emberi jogok mindenkit megilletnek mindenhol. Ez a felfogás köszön vissza már az EJENY 2. cikkében, jóval erősebb formában pedig a PPJNE és a GSZKJNE 2. cikkében.

Jóllehet az emberi jogok elméletében kételyek merültek fel azt illetően, hogy fenntartható-e az emberi jogok időbeli egyetemeségének tétele ${ }^{121}$ kritikák érték továbbá a területi egyetemesség gondolatát is - főként a kulturális relativizmus jegyében $^{122}$-, sőt megszületett az emberi jogok nemzetközi védelmi rendszerének politikai elmélete is, ${ }^{123}$ úgy tünik, mérvadó körök azért kitartanak legalább az emberi jogok személyi és területi egyetemessége mellett. ${ }^{124}$ Ezt tükrözi Mary Robinsonnak, az ENSZ volt emberi jogi főbiztosának az a kijelentése, miszerint „[a]z emberi jogok egyetemessége egyszerüen szólva azt jelenti, hogy az emberi jogoknak ugyanazoknak kell lenniük mindenhol és mindenkinek". ${ }^{125}$ Ezt látszik továbbá az ENSZ egy másik volt emberi jogi főbiztosának, Zeid Ra'ad Al Husseinnek abban a kijelentésében is, hogy az emberi jogok „elidegeníthetetlen jogosultságai mindenkinek, minden időben és minden helyen". ${ }^{126}$

A mondottak szerint ellentmondás van az emberi jogok háromszoros egyetemességének tézise és az EJNT azon cikkei között, amelyek részben vagy egészben területhez kötött, területileg nem egyetemes jogokat ismernek el. Ez az ellentmondás azonban nézetem szerint feloldható: finomítani kell a tézist, elsősorban olyan distinkciókkal, amelyeket a fentiekben már megtettünk.

120 UN Doc. A/C.3/SR.161, 722.

121 Beitz (2011): i. m. 58.

122 Vö. például The Executive Board of American Anthropological Association: Statement on Human Rights. American Anthropologist, 49. (1947), 4. 539-543.

123 Beitz (2011): i. m.

124 Joseph Raz: Human Rights in the Emerging World Order. In Rowan Cruft - Matthew Liao - Massimo Renzo (szerk.): Philosophical Foundations of Human Rights. Oxford, Oxford University Press, 2015. 225; Jack Donnelly: The Relative Universality of Human Rights. Human Rights Quarterly, 29. (2007), 2. 288; John Simmons: Justification and Legitimacy. Cambridge, Cambridge University Press, 2001.185.

125 Mary Robinson: Universality and priorities. Human Development Report 2000. United Nations Development Programme, 2000.

126 Zeid Ra'ad Al Hussein: Foreword. Universal Declaration of Human Rights. United Nations, 2015. 


\section{A területi tipológia jelentőségéről}

Az emberi jogok területi tipológiájának jelentőségét csak akkor lehet majd teljesen felmérni, ha már tisztázott az EJNT által elismert valamennyi jogról, hogy a területhez nem kötött vagy a részben vagy egészben területhez kötött jogok közé tartozik-e. Annyi viszont már most bizonyos, hogy az új tipológia nagymértékben hozzájárulhat az EJNT jobb megértéséhez, a PPJNE és a GSZKJNE koherensebb alkalmazásához, $\mathrm{s}$ az elmélet csiszolódásához is. Ez kisebb-nagyobb változásokat hozhat az EJNT interpretációjában, a PPJNE és a GSZKJNE alkalmazásában, s az emberi jogok elméletében. Láttuk például, hogy a PPJNE 2. cikkének (1) bekezdésében foglalt követelmény egy következtetés eredménye, $\mathrm{s}$ mint ilyen, logikailag hamis, s hogy maga a követelmény statisztikailag sem „általános szabály”, mindazonáltal mindez nem különösebben nehezíti a PPJNE végrehajtását, mert a követelményt megdönthető vélelemnek kell tekinteni. Éppígy láttuk, hogy be kell vezetni a valódi és a látszólagos diszkrimináció fogalmát, s hogy az emberi jogok területi tipológiája szempontjából miként kell értelmezni a PPJNE (és a GSZKJNE) preambulumának az emberi jogok eredetére vonatkozó állítását. Az új tipológia hatással lehet társadalmi, politikai vitákra is, különösen a migráció kérdésében; nézzük, hogyan.

A bevándorlók befogadásáról vagy be nem fogadásáról, illetve a befogadhatók számáról évek óta tart a vita, amely politikai jellegű abban az értelemben, hogy a vitázó felek úgy gondolják: az említett kérdésekben az államok szabadon dönthetnek, nemzetközi normák nem korlátozzák őket. Az új tipológia fényében azonban ez az alapállás bizonyos fokú korrekcióra szorul.

A fentiekben láttuk, hogy a nyelvszabadság, a vallásszabadság és a kultúraszabadság a részben területhez kötött jogok közé tartozik, hogy magánéleti szabadságként mindhárom szabadság megillet mindenkit mindenhol, ugyanakkor mindhárom szabadság közéleti jogosítványai már területhez kötöttek: az egyes államokban megilletik az ott honos személyeket, az ott élő/tartózkodó bevándorlókat és leszármazottjaikat azonban nem. ${ }^{127}$ Egy adott országban így a honos személyek - ha nyelvi, vallási és kulturális szempontból egyaránt honosnak számítanak - teljes mértékben élvezik mindhárom szabadságot, a bevándorlók és leszármazottjaik azonban egyiket sem teljes mértékben. Ez diszkriminációnak látszik, valójában viszont nem az, hiszen láttuk: a bevándorlókat és leszármazottjaikat szintén megilleti mindhárom szabadság teljes mértékben, csak nem új hazájukban, a befogadó államban, hanem származási országukban. Mindazonáltal annak folytán, hogy a honos személyek minden országban teljes mértékben, a bevándorlók és leszármazottjaik viszont csak részben élvezik a nyelvszabadságot, vallásszabadságot és kultúraszabadságot, e három szabadság minden államban jóval erősebben védi a honos nyelveket, a honos vallásokat és a honos kultúrákat, mint a bevándorlók és leszármazottjaik nyelveit, vallásait és kultúráit, s a kisebbségi jogok e különbséget csak növelik.

127 Ez utóbbiakat csak akkor illetik meg e jogosítványok új hazájukban, ha nyelvet és/vagy vallást és/ vagy kultúrát váltottak, ekkor azonban már ők is honos személyeknek számítanak. 
A kérdés ezek után az, hogy vajon megkapják-e a szóban forgó erős védelmet a honos nyelvek és/vagy honos vallások és/vagy honos kultúrák egy országban, ha az állami szervek nagymérvủ bevándorlást engedélyeznek az országba eltérő nyelvű, vallású és/vagy eltérő kultúrájú térségekből? A magam részéről úgy látom, nem. A nagymérvủ bevándorlás eltérő nyelvủ és/vagy eltérő vallású és/vagy eltérő kultúrájú térségekből ugyanis jelentős mértékben átalakítja, megváltoztatja egy ország nyelvhasználatát és/vagy vallási és/vagy kulturális arculatát, $\mathrm{s}$ ez egy ponton túl már rombolja az ország nyelvi és/vagy vallási és/vagy kulturális örökségét is. A helyes emberi jogi válasz ezért szerintem az, hogy az államok korlátozott számban fogadhatnak bevándorlókat eltérő nyelvü és/vagy eltérő vallású és/vagy eltérő kultúrájú térségekből, nagymérvű bevándorlást azonban nem engedélyezhetnek ilyen térségekből, mert ezzel már megsértik a honos nyelvek és/vagy a honos vallások és/vagy a honos kultúrák védelmére a nyelvszabadság, a vallásszabadság és a kultúraszabadság, valamint a kisebbségi jogok tiszteletben tartásával vállalt kötelezettségeiket. ${ }^{128}$

Mindez összhangban áll az EJB-nek azzal a nézetével, miszerint az egyéneket „különleges kapcsolat” vagy „különleges igény” füzi „saját országukhoz”, s éppígy összhangban áll az EUSZ 4. cikkének (2) bekezdésével, Magyarország Alaptörvénye E) cikkének (2) bekezdésével, valamint azokkal az alkotmánybírósági/alkotmánytanácsi állásfoglalásokkal és tudományos érvekkel, amelyek egyes országokban védelmükbe vették az országok alkotmányos és nemzeti identitását. ${ }^{129}$

\section{Irodalomjegyzék}

Andrássy György: Nyelvszabadság. Budapest-Pécs, Dialóg Campus, 2013.

Andrássy György: A magyar nyelv jogállása, a kultúraszabadság és egyes emberi jogok területhez kötöttsége. JURA, 22. (2016), 1. 5-24. Online: https://jura.ajk.pte.hu/JURA_2016_1.pdf Andrássy György: A nyelvszabadság és a hivatalos nyelvek. In Koltay András - Török Bernát (szerk.):

Sajtószabadság és médiajog a 21. század elején. 3. Complex Wolters Kluwer, 2016. 11-52.

Andrássy György: A nagymérvü bevándorlás sérti az emberi jogok nemzetközi jogát. JURA,

23. (2017), 2. 29-43. Online: https://jura.ajk.pte.hu/JURA_2017_2.pdf

Andrássy György: Az emberi jogok területi tagolódása. In Medias Res, 7. (2018), 1. 35-59. Online: https://media-tudomany.hu/archivum/az-emberi-jogok-terulet-szerinti-tagolodasa/

Beitz, R. Charles: The Idea of Human Rights. Oxford, Oxford University Press, 2013. Online: https:// doi.org/10.1093/acprof:oso/9780199572458.001.0001

Bland, Richard: An Inquiry into the Rights of the British Colonies. 1766.

Capotorti, Francesco: Study on the Rights of Persons Belonging to Ethnic, Religious and Linguistic Minorities. New York, United Nations, 1979.

Cicero, Marcus Tullius: Az állam. Budapest, Akadémiai, 1995.

128 Andrássy György: A nagymérvű bevándorlás sérti az emberi jogok nemzetközi jogát. JURA, 23. (2017), 2. 29 és Andrássy György: Az emberi jogok terület szerinti tagolódása. In Medias Res, 7. (2018), 1. 59.

129 Vö. Trócsányi László: Alkotmányos identitás és európai integráció. In Jakab Éva - Pozsonyi Norbert (szerk.): Ünnepi kötet Dr. Molnár Miklós egyetemi tanár 80. születésnapjára. Szeged, Szegedi Tudományegyetem ÁJK, 2014. 473-482. 
Csizmadia Andor - Kovács Kálmán - Asztalos László - Horváth Pál: Magyar állam- és jogtörténet. Budapest, Nemzeti Tankönyvkiadó, 2003.

De Varennes, Fernand: Language, Minorities and Human Rights. The Hague, Martinus Nijhoff, 1996. Online: https://doi.org/10.1163/9789004479258

Donnelly, Jack: Universal Human Rights in Theory and Practice. Ithaca and London, Cornell University, [2003] 2013. Online: https://doi.org/10.7591/9780801467493

Donnelly, Jack: The Relative Universality of Human Rights. Human Rights Quarterly, 29. (2007), 2. 281-306. Online: https://doi.org/10.1353/hrq.2007.0016

Halmai Gábor - Tóth Gábor Attila (szerk.): Emberi jogok. Budapest, Osiris, 2003.

Hamilton, Alexander: The Farmer Refuted. Founders Online, National Archives, 2019. Online: https://founders.archives.gov/documents/Hamilton/01-01-02-0057

Hobbes, Thomas: Leviatán. Magyar Helikon, 1970.

Hussein, Zeid Ra'ad Al: Foreword. In Universal Declaration of Human Rights (booklet). United Nations, 2015. Online: www.un.org/en/udhrbook/foreword.shtml

Joseph, Sarah - Jenny Schultz - Melissa Castan: The International Covenant on Civil and Political Rights, Cases, Materials, and Commentary. Oxford, Oxford University Press, 2003.

Kardos Gábor: A nemzetközi emberijog diszkrétbája. Fundamentum, 2.(1998), 4.5-9. Online:https:// edit.elte.hu/xmlui/bitstream/handle/10831/55583/EPA02334_Fundamentum_1998_04_ 005-009.pdf

Koltay András: A vallások, az állam és a szólás szabadsága. Budapest, Századvég, 2016.

Locke, John: Értekezés a polgári kormányzat igazi eredetéről, hatásköréről és céljáról. Budapest, Gondolat, 1986.

Montreal Statement of the Assembly for Human Rights. Journal of the International Commission of Jurists, 9. (1968), 1. 94-109.

Nowak, Manfred: U.N. Covenant on Civil and Political Rights: CCPR Commentary. Kehl, Engel, 2005.

Pool, Jonathan: The Official Language Problem. American Political Science Review, 85. (1991), 2. 495-514. Online: https://doi.org/10.2307/1963171

Rawls, John: Az igazságosság elmélete. Budapest, Osiris, 1997.

Raz, Joseph: Human Rights in the Emerging World Order. In Rowan Cruft - Matthew Liao - Massimo Renzo (szerk.): Philosophical Foundations of Human Rights. Oxford, Oxford University Press, 2015. 217-231. Online: https://doi.org/10.1093/acprof:oso/9780199688623.003.0012

Robinson, Mary: Universality and priorities. Human Development Report 2000. Online: www.hdr. undp.org/en/content/universality-and-priorities

Schanda Balázs: A gondolat, a lelkiismeret és a vallás szabadsága. Ijoten, 2018. szeptember 14. Online: https://ijoten.hu/szocikk/a-gondolat-a-lelkiismeret-es-a-vallas-szabadsaga

Shue, Henry: Basic Rights. Subsistence, Affluence, and U.S. Foreign Policy. Princeton, Princeton University Press, 1980.

Simmons, John: Justification and Legitimacy. Cambridge, Cambridge University Press, 2001. Online: https://doi.org/10.1017/CBO9780511625152

Simmons, John: Human Rights, Natural Rights, and Human Dignity. In Rowan Cruft - Matthew Liao - Massimo Renzo (szerk.): Philosophical Foundations of Human Rights. Oxford, Oxford University Press, 2015. 138-152. Online: https://doi.org/10.1093/acprof:o so/9780199688623.003.0007 
Statement on Human Rights, by The Executive Board of American Anthropological Association. American Anthropologist, 49. (1947), 4. 539-543. Online: https://doi.org/10.1525/aa.1947. 49.4.02a00020

Trócsányi László: Alkotmányos identitás és európai integráció. In Jakab Éva - Pozsonyi Norbert (szerk.): Ünnepi kötet Dr. Molnár Miklós egyetemi tanár 80. születésnapjára. Szeged, Szegedi Tudományegyetem ÁJK, 2014. Online: http://acta.bibl.u-szeged.hu/37955/1/juridpol_076.pdf

Vašak, Karel: A 30-year Struggle. UNESCO Courier, 30. (1977), 11. 29-32. Online: https://unesdoc. unesco.org/ark:/48223/pf0000074816

Yirush, Craig: The Idea of Rights in the Imperial Crisis. In Ellen Frankel Paul - Fred Miller, Jr. Jeffrey Paul (szerk.): Natural Rights Individualism and Progressivism in American Political Philosophy. Cambridge, Cambridge University Press, 2012. 82-103. Online: https://doi. org/10.1017/CBO9781139237116.004

\section{Jogforrások}

10/1993. (II. 27.) AB határozat, ABH 1993.

CESCR General Comment No. 13.The Right to Education

A Gazdasági, Szociális és Kulturális Jogok Nemzetközi Egyezségokmánya

HRC General Comment No. 15. The position of aliens under the Covenant, 1986.

HRC General Comment No. 17. Rights of the child 1989.

HRC General Comment No. 18. Non-Discrimination, 1989.

HRC General Comment No. 25. The right to participate in public affairs, voting rights and the right of equal access to public service. CCPR/C/21/Rev.1/Add.7 1996.

HRC General Comment No. 27. Freedom of movement, CCPR/C/21/Rev.1/Add.9 1999.

HRC General Comment No. 31. Nature of the general legal obligation on states parties to the Covenant, CCPR/C/21/Rev.1/Add.13. 2004.

Ballantyne, Davidson, McIntyre v. Canada, 358/1989 és 385/1989

Stuart v. Canada (538/93) és Canepa v. Canada (558/93)

Az Amerikai Függetlenségi Nyilatkozat. In Kovács István - Szabó Imre (szerk.): Az emberi jogok dokumentumokban. Budapest, Közgazdasági és Jogi Könyvkiadó, 1980. 633-636.

Az ember és polgár jogainak deklarációja. In Kovács István - Szabó Imre (szerk.): Az emberi jogok dokumentumokban. Budapest, Közgazdasági és Jogi Könyvkiadó, 1980. 119-123.

Az Emberi Jogok Egyetemes Nyilatkozata. In Kovács István - Szabó Imre (szerk.): Az emberi jogok dokumentumokban. Budapest, Közgazdasági és Jogi Könyvkiadó, 1980. 385-393.

A Polgári és Politikai Jogok Nemzetközi Egyezségokmánya

UN Doc. A/2929

UN Doc. CCPR/C/790/Add. 18.

UN Doc. A/C.3/SR.161.

UN Doc. A/C.3/SR.162.

UN Doc. A/Conf.32/41. 